\title{
The Role of Interleukin-23 in the Early Development of Emphysema in HIV1 ${ }^{+}$Smokers
}

\author{
Igor Z. Barjaktarevic, ${ }^{1}$ Ronald G. Crystal, ${ }^{1,2}$ and Robert J. Kaner ${ }^{1,2}$ \\ ${ }^{1}$ Division of Pulmonary and Critical Care Medicine, Weill Medical College of Cornell University, New York, NY 10065, USA \\ ${ }^{2}$ Department of Genetic Medicine, Weill Medical College of Cornell University, New York, NY 10065, USA \\ Correspondence should be addressed to Igor Z. Barjaktarevic; geneticmedicine2@med.cornell.edu
}

Received 27 October 2015; Accepted 19 May 2016

Academic Editor: Nathalie Cools

Copyright (c) 2016 Igor Z. Barjaktarevic et al. This is an open access article distributed under the Creative Commons Attribution License, which permits unrestricted use, distribution, and reproduction in any medium, provided the original work is properly cited.

\begin{abstract}
Rationale. Matrix metalloproteinase-9 (MMP-9) expression is upregulated in alveolar macrophages (AM) of HIV1 ${ }^{+}$smokers who develop emphysema. Knowing that lung epithelial lining fluid (ELF) of $\mathrm{HIV}^{+}$smokers contains increased levels of inflammatory cytokines compared to $\mathrm{HIV1}^{-}$smokers, we hypothesized that upregulation of lung cytokines in $\mathrm{HIV1}^{+}$smokers may be functionally related to increased MMP-9 expression. Methods. Cytokine arrays evaluated cytokine protein levels in ELF obtained from 5 groups of individuals: $\mathrm{HIV}^{-}$healthy nonsmokers, $\mathrm{HIV1}^{-}$healthy smokers, $\mathrm{HIV}^{-}$smokers with low diffusing capacity $\left(\mathrm{DL}_{\mathrm{CO}}\right), \mathrm{HIV1}^{+}$ nonsmokers, and $\mathrm{HIV1}^{+}$smokers with low $\mathrm{DL}_{\mathrm{CO}}$. Results. Increased levels of the Th17 related cytokine IL-23 were found in $\mathrm{HIV1}^{-}$ smokers with low $\mathrm{DL}_{\mathrm{CO}}$ and $\mathrm{HIV1}^{+}$smokers and nonsmokers. Relative IL-23 gene expression was increased in $\mathrm{AM}^{\circ} \mathrm{HIV1}^{+}$ individuals, with greater expression in $\mathrm{AM}_{\text {of }} \mathrm{HIVl}^{+}$smokers with low $\mathrm{DL}_{\mathrm{CO}}$. Infection with $\mathrm{HIV} 1$ in vitro induced IL-23 expression in normal AM. IL-23 stimulation of AM/lymphocyte cocultures in vitro induced upregulation of MMP-9. Lung T lymphocytes express receptor IL-23R and interact with AM in order to upregulate MMP-9. Conclusion. This mechanism may contribute to the increased tissue destruction in the lungs of $\mathrm{HIV}^{+}$smokers and suggests that Thl7 related inflammation may play a role.
\end{abstract}

\section{Introduction}

Survival of individuals infected with HIV1 has been dramatically improved since the introduction of highly active antiretroviral therapy (HAART), but this increased survival has been associated with the development of chronic disorders [1]. One example is the early development of emphysema in $\mathrm{HIV}^{+}$smokers, with a greater prevalence compared to smokers who are $\mathrm{HIV1}^{-}$[2-5]. Relevant to the pathogenesis of this $\mathrm{HIVl}^{+}$smoker-associated early emphysema, alveolar macrophages (AM) of $\mathrm{HIV1}^{+}$smokers release increased levels of matrix metalloproteinases (MMPs), enzymes thought to play a key role in the pathogenesis of emphysema by virtue of their ability to degrade extracellular matrix and basement membrane components and modulate the recruitment of leukocytes into the lung [6-8].

In the context that lung epithelial lining fluid (ELF) of $\mathrm{HIVI}^{+}$smokers has increased levels of a variety of cytokines
$[5,7-10]$ and that several cytokines mediate the activation state of AM [11, 12], we hypothesized that, in the presence of cigarette smoke, upregulation of MMP-9 is associated with increased levels of proinflammatory cytokines and that their interplay may be contributing to the early development of emphysema in $\mathrm{HIVl}^{+}$smokers. Based on recent studies demonstrating the importance of IL-23 and the Th17 immune response in the development of chronic obstructive pulmonary disease [13-15], their role in the progression of HIV-1 infection [16-20], and the effect of IL-23 on increased lung MMP-9 in mice [21], we focused on a possible role of IL23 in the upregulation of MMP-9 in AM of $\mathrm{HIV1}^{+}$smokers. Assessment of inflammatory/immune cells recovered by lavage and lower respiratory tract ELF of $\mathrm{HIV1}^{-}$healthy nonsmokers, $\mathrm{HIV1}^{+}$nonsmokers, $\mathrm{HIV}^{-}$healthy smokers, $\mathrm{HIV1}^{-}$smokers with low $\mathrm{DL}_{\mathrm{CO}}$ and $\mathrm{HIV}^{+}$smokers with low $\mathrm{DL}_{\mathrm{CO}}$ demonstrates that the upregulation of the MMP-9 by

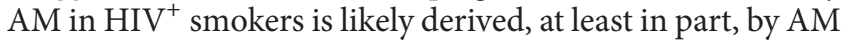


expression of IL-23 working in concert with T lymphocytes to induce AM to express MMP-9, a known contributor to the pathogenesis of emphysema [22].

\section{Methods}

2.1. Human Subjects. All individuals were evaluated at the Weill Cornell NIH Clinical and Translational Science Center and the Department of Genetic Medicine Clinical Research Facility, using Institutional Review Board-approved clinical protocols. Individuals underwent an initial screening evaluation including history, complete physical exam, blood studies, urine analysis, chest X-ray, pulmonary function tests, and electrocardiogram. Individuals with any significant prior use of addictive drugs (other than nicotine) in the previous 6 months were excluded. Blood studies included a complete blood count, coagulation parameters, serum electrolytes, liver and kidney function tests, serum evaluation for human immunodeficiency virus antibodies, HIV1 viral load, CD4 count, hepatitis profile (A, B, and C), anti-nuclear antibodies, sedimentation rate, and rheumatoid factor. Current smoking status was verified by measurement of urinary levels of nicotine and its derivative cotinine and blood carboxyhemoglobin. Pulmonary function tests were carried out according to American Thoracic Society guidelines [21, 23-26]. Individuals who smoked and had a diffusing capacity $<80 \%$ predicted were further evaluated with noncontrast high resolution computed tomography (CT) of the chest. The 5 subject groups were defined as follows (Table 1). For all groups, no subjects had active pulmonary symptoms or a history of lung infections.

2.1.1. $\mathrm{HIV1}^{+}$Smokers with Low $\mathrm{DL}_{\mathrm{CO}}$. This group $(n=$ 11) included individuals who were $\mathrm{HIV}^{+}$and were current smokers. All subjects reported taking HAART. Each of these individuals had lung function studies with normal forced expiratory volume in $1 \mathrm{sec}$ (FEV1), forced vital capacity (FVC), FEV1/FVC, and total lung capacity (TLC), but with diffusing capacity $<80 \%$ predicted as a physiological correlate of early emphysema $[27,28]$. Assessment of the chest highresolution CT (HRCT) of this group had visual evidence of minimal to mild emphysema in $8 / 11$ subjects confirmed by two experienced pulmonary physicians and a radiologist who was blinded to the subjects' history.

2.1.2. HIV1- Smokers with Low $\mathrm{DL}_{\mathrm{CO}}$. This group $(n=18)$ were characterized by the same pulmonary function as for the $\mathrm{HIV}^{+}$smokers. A chest HRCT was available for the majority of subjects in the study group and revealed visual changes of minimal to mild emphysema in $9 / 14$.

2.1.3. $\mathrm{HIV1}^{-}$Healthy Smokers. These individuals $(n=32)$ included current smokers with a normal screening evaluation, normal pulmonary function tests and chest X-ray, and a positive urine screen for smoking.

2.1.4. HIV1 ${ }^{-}$Healthy Nonsmokers. These individuals $(n=$ 17) were lifelong nonsmokers with a normal screening evaluation, normal pulmonary function tests and chest X-ray, and a negative urine screen for smoking.

2.1.5. $\mathrm{HIVI}^{+}$Nonsmokers. This group $(n=5)$ consisted of lifelong $\mathrm{HIV}^{+}$nonsmokers with an otherwise normal screening evaluation, normal pulmonary function tests and chest X-ray, and a negative urine screen for smoking.

For the in vitro analyses, each assay was performed on a random subset of the overall study group; the number of subjects used for each analysis is indicated.

\subsection{Collection of Alveolar Macrophage/Lymphocyte Cocul-} tures. Fiberoptic bronchoscopy was performed to obtain inflammatory/immune cells and ELF from the lower respiratory tract using bronchoalveolar lavage, as previously described [8]. The lavage fluid was filtered through 2 layers of gauze and centrifuged at $1250 \mathrm{rpm}$ for $5 \mathrm{~min}, 4^{\circ} \mathrm{C}$. The supernatant was aliquoted and stored at $-80^{\circ} \mathrm{C}$. Cells were suspended in $5 \mathrm{~mL}$ Ack Lysing Buffer (Invitrogen ${ }^{\mathrm{TM}}$, Grand Island, NY) and then washed twice in RPMI 1640 containing $10 \%$ fetal bovine serum, $50 \mathrm{U} / \mathrm{mL}$ penicillin, $50 \mu \mathrm{g} / \mathrm{mL}$ streptomycin, and $2 \mathrm{mM}$ glutamine (Invitrogen). Cell viability was estimated by trypan blue exclusion and expressed as a percentage of the total cells recovered. Total cell number was determined by counting in a hemocytometer. Cells were suspended in media $\left(10^{6}\right.$ cells $\left./ \mathrm{mL}\right)$ and an aliquot of $250 \mu \mathrm{L}$ with $250 \mu \mathrm{L}$ fetal bovine serum (Invitrogen) was used for a differential cell count assessed by cytocentrifugation (Cytospin 11; Shandon Instruments, Pittsburgh, PA) and stained with DiffQuik (Baxter Healthcare, Miami, FL). Cells recovered from BAL fluid were seeded in 12-well plastic culture dishes $\left(10^{6} /\right.$ well) and alveolar macrophages (AM) were enriched by adherence for $12 \mathrm{hr}$ at $37^{\circ} \mathrm{C}$ in a $5 \% \mathrm{CO}_{2}$ humidified incubator. Nonadherent cells were removed by thorough washing with RPMI 1640 . AM represented $\geq 95 \%$ of cells, consistent with published literature [29]. The remaining cells consisted of lymphocytes, neutrophils, NK cells, or eosinophils as assessed by flow cytometric analysis (not shown). Because this adherence method for AM isolation is known to contain a small number of lymphocytes, we refer to the cultures as AM/lymphocyte cocultures.

2.3. Cell Cultures. All cells including AM, T cells recovered from the lower respiratory tract, and $\mathrm{T}$ cells from blood were cultured from $6 \mathrm{~h}$ to $48 \mathrm{~h}$ at $37^{\circ} \mathrm{C}$ in a $5 \% \mathrm{CO}_{2}$ humidified incubator in RPMI 1640 medium supplemented with $10 \%$ fetal bovine serum, $50 \mathrm{U} / \mathrm{mL}$ penicillin, $50 \mu \mathrm{g} / \mathrm{mL}$ streptomycin, and $2 \mathrm{mM}$ glutamine (Invitrogen). Cell viability was estimated by trypan blue exclusion and expressed as \% total cells.

2.4. Cytokine Protein Arrays. Lavage fluid supernatant was concentrated 10-fold on Centricon filters (Millipore, Billerica, MA). The concentrated supernatant was assessed for 36 cytokines with a Human Cytokine Array Panel A (R\&D Systems, Minneapolis, MN). The supernatant was mixed with a cocktail of biotinylated detection antibodies and incubated 
TABLE 1: Study population and alveolar macrophage samples ${ }^{(1)}$.

\begin{tabular}{|c|c|c|c|c|c|}
\hline Parameter & $\begin{array}{c}\text { Healthy HIV1 }^{-} \\
\text {nonsmoker }\end{array}$ & $\begin{array}{c}\mathrm{HIV1}^{+} \\
\text {nonsmoker }^{(7)}\end{array}$ & $\begin{array}{c}\text { Healthy HIV1- } \\
\text { smoker }\end{array}$ & $\begin{array}{c}\text { HIV1 }^{-} \text {smoker } \\
\text { with low DLCO }\end{array}$ & $\begin{array}{c}\text { HIV1 }^{+} \text {smoker } \\
\text { with low } \mathrm{DLCO}^{(8)}\end{array}$ \\
\hline$N$ & 6 & 4 & 7 & 6 & 4 \\
\hline Gender (male/female) & $5 / 1$ & $2 / 2$ & $3 / 4$ & $6 / 0$ & $2 / 2$ \\
\hline Age (yr) & $41 \pm 2$ & $44 \pm 6$ & $44 \pm 2$ & $47 \pm 2$ & $46 \pm 1$ \\
\hline $\operatorname{Race}(\mathrm{B} / \mathrm{W} / \mathrm{O})^{(2)}$ & $4 / 1 / 1$ & $2 / 1 / 1$ & $3 / 2 / 2$ & $6 / 0 / 0$ & $4 / 0 / 0$ \\
\hline Smoking history (pack-yr) & 0 & 0 & $31 \pm 8$ & $48 \pm 9$ & $27 \pm 7$ \\
\hline Urine nicotine $(\mathrm{ng} / \mathrm{mL})^{(3)}$ & Negative & Negative & $1328 \pm 623$ & $1817 \pm 566$ & $813 \pm 307$ \\
\hline Urine cotinine $(\mathrm{ng} / \mathrm{mL})^{(3)}$ & Negative & Negative & $973 \pm 273$ & $1277 \pm 438$ & $1419 \pm 561$ \\
\hline Blood carboxyhemoglobin (\%) $)^{(4)}$ & $0.5 \pm 0.4$ & 0 & $2.6 \pm 1.5$ & $1.2 \pm 0.3$ & $2.0 \pm 0.8$ \\
\hline \multicolumn{6}{|l|}{ Pulmonary function parameters ${ }^{(5)}$} \\
\hline FVC & $103 \pm 3$ & $104 \pm 11$ & $110 \pm 5$ & $108 \pm 5$ & $103 \pm 7$ \\
\hline FEV1 & $107 \pm 2$ & $105 \pm 11$ & $106 \pm 6$ & $108 \pm 2$ & $115 \pm 8$ \\
\hline FEV1/FVC & $85 \pm 1$ & $83 \pm 2$ & $80 \pm 2$ & $80 \pm 2$ & $83 \pm 2$ \\
\hline TLC & $91 \pm 4$ & $102 \pm 9$ & $95 \pm 3$ & $88 \pm 3$ & $90 \pm 6$ \\
\hline DLCO & $92 \pm 5$ & $91 \pm 3$ & $99 \pm 5$ & $68 \pm 4$ & $69 \pm 5$ \\
\hline \multicolumn{6}{|l|}{ BAL cells ${ }^{(6)}$} \\
\hline Total number recovered $\left(\times 10^{7}\right)$ & $2.1 \pm 0.4$ & $3.3 \pm 0.8$ & $2.9 \pm 1.0$ & $3.3 \pm 0.8$ & $3.7 \pm 0.9$ \\
\hline$\%$ viability & $92.0 \pm 2.0$ & $80.4 \pm 8.6$ & $95.3 \pm 1.0$ & $93.1 \pm 1.5$ & $87.3 \pm 3.5$ \\
\hline$\%$ lymphocytes & $5.5 \pm 1.3$ & $6.9 \pm 2.4$ & $2.6 \pm 0.6$ & $2.3 \pm 0.5$ & $13.0 \pm 5.2$ \\
\hline$\%$ alveolar macrophages & $91.7 \pm 1.7$ & $89.8 \pm 2.9$ & $94.6 \pm 1.2$ & $97.2 \pm 0.8$ & $87.5 \pm 4.0$ \\
\hline$\%$ polymorphonuclear cells & $1.0 \pm 0.3$ & $1.7 \pm 0.7$ & $1.2 \pm 0.6$ & $0.5 \pm 0.2$ & $0.5 \pm 0.2$ \\
\hline$\%$ epithelial cells & $0.8 \pm 0.5$ & $1.7 \pm 0.3$ & $0.3 \pm 0.32$ & $0.3 \pm 0.1$ & $0.7 \pm 0.4$ \\
\hline
\end{tabular}

${ }^{(1)}$ Demographic characteristics of subjects; bronchoalveolar lavage cell differentials represent the samples used to obtain the data; all data are mean \pm standard error.

${ }^{(2)} \mathrm{B}=$ black; $\mathrm{W}=$ white; $\mathrm{O}=$ other.

${ }^{(3)}$ Urine nicotine and cotinine $>200=$ active smoker, 50-200 = passive smoker; $<50$ nonsmoker; data represent the mean of two determinations on the days of screening and bronchoscopy.

${ }^{(4)}$ Blood carboxyhemoglobin is a secondary marker of current smoking status; nonsmokers $<1.5 \%$.

${ }^{(5)}$ Pulmonary function parameters included: FVC, forced vital capacity (\% predicted); FEV1, forced expiratory volume in 1 sec; FEV1/FVC (\% observed); TLC, total capacity (\% predicted); DLCO, diffusion capacity (\% predicted).

${ }^{(6)} \mathrm{BAL}=$ bronchoalveolar lavage; shown is the cell differential prior to alveolar macrophage purification.

${ }^{(7)}$ Individual plasma HIV1 viral loads: $<50(n=2)$; 16,000; unknown $(n=1)$. Individual CD4 count: 700; 696; 450; unknown $(n=1)$.

${ }^{(8)}$ Individual plasma HIV1 viral loads: $<50(n=2)$; 8000; unknown $(n=1)$. Individual CD4 count: 384; 1070; 494; unknown $(n=1)$.

on a nitrocellulose membrane, embedded with cognate capture antibodies. Arrays were then treated with streptavidinhorseradish peroxidase for $30 \mathrm{~min}$. Chemiluminescent detection reagents were added (GE Healthcare, Piscataway, NJ) and the array was developed. The signal present was proportional to the amount of cytokine captured. Optical densities of obtained values were measured and quantified using Image J software.

2.5. TaqMan PCR. Relative gene expressions of IL-23, IL23R, and MMP-9 were evaluated by measuring specific mRNA levels via TaqMan real-time reverse transcriptase (RT) PCR analysis. Total RNA was extracted using a modified version of the TRIzol method (Invitrogen, Grand Island, NY), in which RNA is purified directly from the aqueous phase (RNeasy MinElute RNA purification kit, Qiagen, Valencia, CA). RNA samples were stored in RNA Secure (Ambion, Austin, TX) at $-80^{\circ} \mathrm{C}$. RNA integrity was determined by running an aliquot of each RNA sample on an Agilent
Bioanalyzer (Agilent Technologies, Palo Alto, CA). The concentration was determined using a NanoDrop ND-1000 spectrophotometer (NanoDrop Technologies, Wilmington, $\mathrm{DE})$. A first-strand cDNA was synthesized from $2 \mu \mathrm{g}$ of total RNA in $50 \mu \mathrm{L}$ reaction volume, using the TaqMan Reverse Transcriptase Reaction Kit (Applied Biosystems, Foster City, CA), with random hexamers as primers. The primers specific for each mRNA (MMP-9: hs00234579_m1, IL-23a: hs00900829_g1, and IL-23R: hs00332759_ml) and the endogenous controls human $\beta$-2-microglobulin (VIC ${ }^{\circledR} / \mathrm{MGB}$ Probe, Primer Limited) and human $\beta$-actin endogenous control (VIC/MGB Probe, Primer Limited) were purchased from Applied Biosystems. For each individual sample, two conditions were used: $1: 10$ and 1:100 dilution of the cDNA reaction, and each dilution was assayed in triplicate wells. The PCR reactions were run in an Applied Biosystems Sequence Detection System 7700. The threshold cycles (Cts) were calculated as an average of the triplicate reactions for each condition, and the $\Delta \mathrm{Ct}$ was calculated for each sample using 
the rRNA as an endogenous reference. $\Delta \Delta \mathrm{Ct}$ was calculated by subtracting the calibrator from the $\Delta \mathrm{Ct}$ in each individual sample using the algorithm provided by Applied Biosystems.

\subsection{Cytokine Treatment of AM/Lymphocyte Cocultures. After} removal of nonadherent cells from the lavage fluid, cultured AM containing small numbers of lymphocytes from both $\mathrm{HIV1}^{+}$and $\mathrm{HIV1}^{-}$individuals were incubated with RPMI media in 12 -well plates at $37^{\circ} \mathrm{C}$ in a $5 \% \mathrm{CO}_{2}$ humidified incubator. AM were treated with serum-free media alone or with serum-free media containing rhIL-23 (R\&D systems) at various concentrations. Treated AM/lymphocytes were cultured overnight for quantitative cDNA analysis or 48 hours for the analysis of substrate (MMP-9) concentration in conditioned media.

2.7. Gelatin Zymography. For analysis of MMP-9 activity, gelatin zymography was carried out by loading equal amounts of protein per sample onto $8 \%$ sodium dodecyl sulfate polyacrylamide gels impregnated with $0.1 \%$ gelatin (Invitrogen) and separated using nondenaturing electrophoresis. After electrophoresis, the gels were soaked in renaturing buffer with 2.7\% Triton X-100 in distilled water (Invitrogen). Gels were then developed and stained with Colloidal Blue (Invitrogen) which reveals the enzymatic activity with white bands against a dark background. Recombinant MMP-9 protein in latent and active forms (Chemicon, Temecula, CA) was used as a positive control. Optical densities of gel zymograms were quantified with Image J software.

2.8. $\mathrm{HIV1}^{-}$Infection of Normal AM. HIV1 ${ }^{-}$AM $\left(2-3 \times 10^{5} /\right.$ well) were infected with the HIV-1 laboratory strain, JRFL, at $10^{3}$ median tissue culture infectious doses (TCID50) per well, a dose known to infect cells of monocytic origin [30]. After 12 days of incubation at $37^{\circ} \mathrm{C}$, the cells were washed and the RNA was isolated. Productive HIV1 infection by JRFL HIV1 was determined by quantifying p24 antigen in the media supernatant by ELISA (Beckman Coulter, Miami, FL) at 012 days after HIV1 JRFL infection.

2.9. T Cell Isolation. T cells used in functional experiments ( $T$ cells added to cultures of AM) were isolated directly from BAL using $\mathrm{T}$ cell rosetting with neuraminidase-treated sheep red blood cell as per standard protocol $[31,32]$. T cells used for cDNA analysis were isolated directly from BAL via positive selection using Dynabeads ${ }^{\circledR}$ CD2 Pan T (Invitrogen Dynal, Life Technologies, Grand Island, NY) as per manufacturer's recommendations. T cells isolated by this method had purity $>80 \%$ and were used for cDNA quantitative PCR analysis.

2.10. AM Purification Using CD68. Purification of AM was based on positive selection of cells expressing CD68, a glycoprotein expressed intracellularly as well as on the surface of macrophages but not on lymphocytes [33]. DSB-X labeled (Molecular Probes, Inc. Eugene, OR) LEAF mouse antihuman anti-CD68 antibody (BioLegend, San Diego, CA) was used to attach to CD68+ AM. Addition of FlowComp Flexi detachable beads (Invitrogen Dynal, Life Technologies,
Grand Island, NY) was used to positively isolate CD68+ AM. Magnetic beads were detached using streptavidin reagent as per the manufacturer's recommendations. Estimated purity of positively selected cells prior to the detachment of magnetic beads was estimated to be $>90 \%$.

2.11. Flow Cytometry. Cells directly isolated from BAL or cultured AM/lymphocytes isolated by adherence were detached from plates using ethylenediaminetetraacetic acid (EDTA; $5 \mathrm{mM}$ ) for $3 \mathrm{~min}$ with vigorous washing and were thereafter washed with $0.1 \%$ bovine serum albumin (BSA). The cells were then labeled with monoclonal anti-CD-68-PE and antihuman IL-23R-PE (R\&D Systems) at $4^{\circ} \mathrm{C}$ for $30 \mathrm{~min}$. The cells were then fixed and permeabilized and immediately analyzed by flow cytometry. Data on a minimum of 20,000 cell fluorescence events were acquired and analyzed using a FACSCalibur instrument (Becton-Dickinson, San Jose, Calif) and CellQuest ${ }^{\mathrm{TM}}$ software. Immediately prior to the analysis, $\mathrm{AM}$ were quenched with Crystal violet $0.5 \%$ [34].

2.12. Affymetrix Microarrays. Analysis was performed using Affymetrix (Santa Clara, CA) microarray HG-U133 Plus 2.0 and associated protocols. An aliquot of each RNA sample was run on an Agilent Bioanalyzer (Agilent Technologies, Palo Alto, CA) to visualize and quantify the degree of RNA integrity. The concentration was determined using a NanoDrop ND-1000 spectrophotometer (NanoDrop Technologies, Wilmington, DE, USA). Strict quality control criteria were used for an RNA sample to be accepted for further processing [35]. Double-stranded cDNA was synthesized from $3 \mu \mathrm{g}$ of total RNA using the GeneChip One-Cycle cDNA Synthesis Kit, followed by cleanup with GeneChip Sample Cleanup Module, in vitro transcription reaction using the GeneChip IVT Labeling Kit, and cleanup and quantification of the biotin-labeled cRNA yield by spectrophotometric analysis. All kits were from Affymetrix. Hybridizations to test chips and to microarrays were performed according to Affymetrix protocols, and microarrays were processed by the Affymetrix fluidics station and scanned with the Affymetrix GeneChip Scanner 3000 7G. The overall microarray quality was verified by the criteria: (1) $3^{\prime} / 5^{\prime}$ ratio for GAPDH $<3$; (2) scaling factor range no more than 2.5 standard deviations (SD) from the mean for all microarrays; and (3) expression level for all 100 housekeeping genes (as defined by Affymetrix, http://www.affymetrix.com/estore/) with coefficient of variation of $<40 \%$. After scanning, the data on each individual microarray were scaled to an arbitrary target intensity as recommended by Affymetrix, using the Microarray Suite version 5.0 software.

2.13. RNA Sequencing. Analysis of the interleukin-23 receptor (IL-23R) gene was carried out using a database of massive parallel sequencing (RNA-seq) of the transcriptome of AM of $\mathrm{HIV1}^{-}$nonsmokers. The resultant reads were aligned to Homo sapiens high coverage assembly GRCh37 using Bowtie $\mathrm{v}$ 0.12. Reads per kilobase of exon model per million mapped reads (RPKM) were used to quantify transcript levels of the gene. 
2.14. Statistics. Results of ELF cytokine protein arrays were expressed as mean values of protein concentration \pm standard deviation relative to an array internal standard and were displayed on a logarithmic scale. The significance of differences of mean values of demographic data between the 5 groups was analyzed by ANOVA. TaqMan analysis results were expressed as a relative gene expression in comparison to control and/or the lowest expression in particular experiments. The significance of differences in relative gene expression between different phenotypes was tested via ANOVA or Kruskal-Wallis test when the number of compared groups was $>2$; Student $t$-test or Wilcoxon Signed-Rank Test was used to compare relative gene expression when 2 groups were compared. $p<0.05$ was considered significant.

\section{Results}

3.1. Cytokine Profile of Epithelial Lining Fluid of $\mathrm{HIVI}^{+}$ Smokers with Low Diffusing Capacity. A multicytokine array was used to evaluate ELF levels in 27 individuals, including $\mathrm{HIV}^{+}$and $\mathrm{HIV}^{-}$nonsmokers, smokers, and smokers with low $\mathrm{DL}_{\mathrm{CO}}$ (see Table 1 for demographic data). As expected, a relatively small number of cytokines were detectable in the ELF of $\mathrm{HIV1}^{-}$healthy smokers and $\mathrm{HIV}^{-}$ healthy nonsmokers. In contrast, smokers with low $\mathrm{DL}_{\mathrm{CO}}$ independent of their HIV1 status had a significantly higher proportion of detectable cytokines (Supplemental Figure 1; see Supplemental Table I for definitions of all cytokines in the arrays, at Supplementary Material available online at http://dx.doi.org/10.1155/2016/3463104).

In stark contrast to $\mathrm{HIV1}^{-}$nonsmokers or $\mathrm{HIV1}^{-}$healthy smokers, $\mathrm{HIV1}^{+}$nonsmokers had detectible amounts of more than $2 / 3$ of the cytokines represented on the array and more than twice as many compared to HIV1 ${ }^{-}$healthy nonsmokers. Interestingly, the cytokine profiles of $\mathrm{HIV}^{+}$nonsmokers, $\mathrm{HIV1}^{-}$smokers with low $\mathrm{DL}_{\mathrm{CO}}$, and $\mathrm{HIV1}^{+}$smokers with low $\mathrm{DL}_{\mathrm{CO}}$ were very similar and were characterized by the presence of IFN- $\gamma$ as well as the Th17 related cytokines IL17 and IL-23 that were not present in $\mathrm{HIV1}^{-}$nonsmokers or $\mathrm{HIV1}^{-}$smokers (Figure 1).

These data support the concept that proinflammatory cytokines are increased in the lungs of smokers with low $\mathrm{DL}_{\mathrm{CO}}$, in both $\mathrm{HIVl}^{+}$and $\mathrm{HIV}^{-}$individuals. $\mathrm{HIV1}^{+}$infection itself leads to a broad upregulation of cytokines detectable in ELF, even in the absence of smoking. The presence of IL-23 and IL-17 that characterizes $\mathrm{HIV}^{+}$individuals independent of their smoking status, as well as $\mathrm{HIV1}^{-}$smokers with low $\mathrm{DL}_{\mathrm{CO}}$, suggests a potential role of Th17 cellular immune responses in the pathogenesis of emphysema in $\mathrm{HIV}^{+}$ smokers.

In addition to IFN- $\gamma$ and Th17 cytokines, the cytokine profile of $\mathrm{HIV1}^{+}$smokers with low $\mathrm{DL}_{\mathrm{CO}}$ shared other features with $\mathrm{HIV}^{+}$nonsmokers and $\mathrm{HIV1}^{-}$smokers with low $\mathrm{DL}_{\mathrm{CO}}$ including the presence of chemokine (C-C motif) ligand 1 (CCL-1) and chemokine (C-X-C motif) ligand 11 (CXCL-11), both chemotactic for activated T cells $[36,37]$. The presence of both of these chemokines is consistent with a role for adaptive immunity and T cells in the early development of emphysema in $\mathrm{HIV}^{+}$smokers.
3.2. IL-23 Expression in Human Alveolar Macrophages. To evaluate whether the IL-23 gene was expressed in human AM, relative expression of AM IL-23 was quantified in a subset of all phenotypes using TaqMan real-time RT-PCR. AM IL23 expression was detected in all phenotypes. IL-23 was upregulated in both $\mathrm{HIV}^{+}$phenotypes compared to $\mathrm{HIV1}^{-}$ phenotypes ( $\mathrm{HIV1}^{-}$nonsmokers $(n=5), \mathrm{HIV1}^{-}$smokers $(n=5), \mathrm{HIVl}^{+}$nonsmokers $(n=4), \mathrm{HIVl}^{-}$smokers with low $\mathrm{DL}_{\mathrm{CO}}(n=4)$, and $\mathrm{HIV1}^{+}$smokers with low $\mathrm{DL}_{\mathrm{CO}}(n=4$; $p<0.05$, Kruskal-Wallis; Figure 2)). These data are consistent with the results of HG-U133 Plus 2.0 gene microarray analysis where IL-23 expression in AM from $\mathrm{HIVl}^{+}$smokers with low $\mathrm{DL}_{\mathrm{CO}}(n=11)$ was significantly higher compared to its expression in $\mathrm{HIVI}^{-}$smokers with low $\mathrm{DL}_{\mathrm{CO}}(n=23$; not shown). In contrast, there was no significant difference in the extent of upregulation of IL-23 in smoking compared to nonsmoking phenotypes. These data indicate that HIV1 infection correlates with the increased AM expression of IL23.

3.3. Effect of In Vitro HIV1 Infection on AM IL-23 Expression. To assess the effect of HIV1 infection on AM production of IL23 , we used an established model of in vitro infection of AM with an HIV1 laboratory strain, JRFL [30]. IL-23 expression in JFRL-infected AM was compared to IL-23 expression in uninfected control AM. At day 12, IL-23 expression was increased 10-fold compared to uninfected AM, showing a positive trend, but without statistical significance due to high variability associated with JRFL-infected AM $(p=0.06$, Wilcoxon Signed-Rank Test, Figure 3). This may provide one possible explanation for the increased presence of IL-23 in the ELF of $\mathrm{HIVl}^{+}$individuals independently from their smoking history. This observation is also consistent with the results of experiments in which we measured the levels of IL-23 in conditioned media of AM cultured for $48 \mathrm{hr}$. Additionally, in a set of experiments with LPS, we also confirmed that IL-23 is inducible in normal AM without HIV1 infection (Supplemental Figure 2). This can explain how, in the setting of chronic inflammation of the airways as in COPD, IL-23 may be present at increased levels, consistent with previously published literature $[13,15,20,21]$. While our experimental design did not target recruitment of individuals with poorly controlled HIV disease, two available cultures of AM from individuals with measurable viral loads had spontaneous IL23 release that was 10 -fold higher than $\mathrm{AM}$ from $\mathrm{HIV1}^{-}$ individuals (not shown).

3.4. Effect of IL-23 on AM MMP-9 in AM/Lymphocyte Cocultures. The gelatinase MMP-9 is capable of degrading extracellular matrix proteins and also can activate a number of bioactive molecules such as chemokines that are not a part of the matrix $[38,39]$. Based on the data shown in Figure 1 and our prior observations that expression of AM MMP-9 is significantly increased in both $\mathrm{HIV1}^{+}$smokers with low $\mathrm{DL}_{\mathrm{CO}}$ and $\mathrm{HIV1}^{-}$smokers with low $\mathrm{DL}_{\mathrm{CO}}$ compared to both $\mathrm{HIV}^{-}$healthy smokers and $\mathrm{HIV1}^{-}$healthy nonsmokers [8], we analyzed the effect of IL-23 on AM MMP-9 production. We used AM/lymphocyte cocultures obtained from $\mathrm{HIV1}^{-}$ 


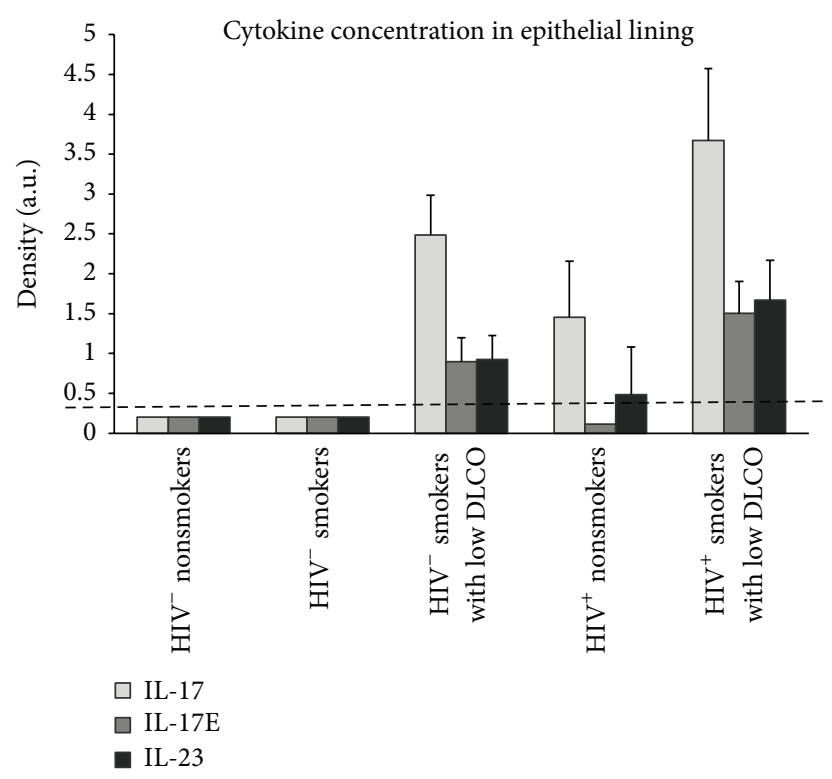

FIGURE 1: The levels of Th17 cytokines in epithelial lining fluid were analyzed with the Proteome Profiler ${ }^{\mathrm{TM}}$ Human Cytokine Array Panel and average values of $\mathrm{HIV1}^{-}$healthy nonsmokers $(n=6)$, HIV1 ${ }^{-}$ healthy smokers $(n=7)$, $\mathrm{HIV1}^{-}$smokers with low DLCO $(n=6)$, $\mathrm{HIV1}^{+}$nonsmokers $(n=4)$, and $\mathrm{HIVl}^{+}$smokers with low DLCO $(n=4)$ are presented in the graph.

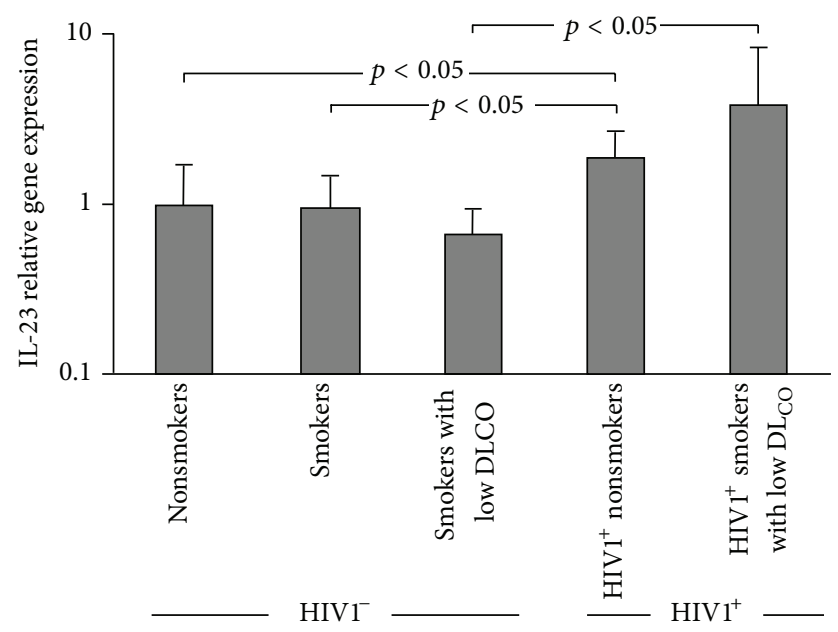

FIgURE 2: IL-23 expression in $\mathrm{AM}$ of $\mathrm{HIV1}^{-}$and $\mathrm{HIV1}^{+}$smokers. Shown is TaqMan PCR analysis of IL-23 expression in AM of $\mathrm{HIV1}^{-}$ nonsmokers $(n=5)$, $\mathrm{HIV1}^{-}$smokers $(n=5), \mathrm{HIV1}^{-}$smokers with low DLCO $(n=4), \mathrm{HIV1}^{+}$nonsmokers $(n=4)$, and $\mathrm{HIV1}^{+}$smokers with low DLCO $(n=4)$. Values represent mean relative gene expression in each phenotype compared to mean IL-23 expression in nonsmokers. $p$ values shown are based on the Kruskal-Wallis test.

healthy smokers, stimulated the cultures with IL-23, and then analyzed the relative expression of MMP-9 mRNA with TaqMan RT-PCR. Treatment of AM/lymphocyte cocultures with IL-23 leads to a mild but consistent upregulation of MMP-9 relative gene expression $(n=13, p<0.01$, ANOVA,

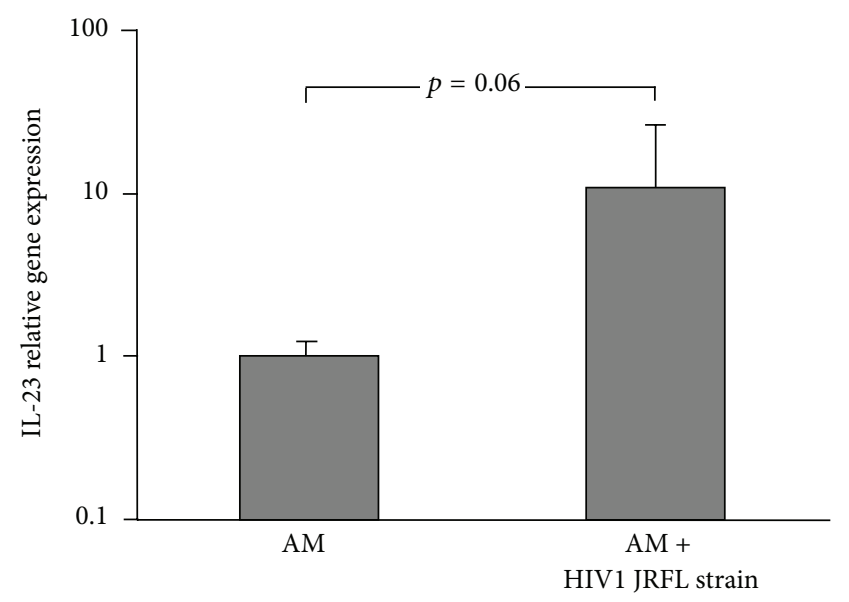

FIgURE 3: Effect of HIV1 infection in vitro on AM-IL-23 upregulation. AM isolated from HIV1 ${ }^{-}$individuals $(n=5)$ were infected with HIV1 JRFL $10^{3} \mathrm{TCID} /$ well or left uninfected. At day 12, RNA was isolated and relative IL-23 expression was assessed by TaqMan PCR (mean \pm SEM, $p=0.06$, Wilcoxon Signed-Rank Test).

Figure 4(a)). To assess whether IL-23 causes increased secretion of MMP-9, we analyzed the concentrations of MMP-9 in conditioned media via gelatin zymography (Figure 4(b)). Stimulation of AM/lymphocyte cocultures with IL-23 leads to an increase in MMP-9 concentration in conditioned media in a dose-dependent fashion $(n=24, p<0.001$, ANOVA, Figure 4(c)). This increase in MMP-9 concentration showed a similar pattern in all tested phenotypes including $\mathrm{HIV1}^{-}$ nonsmokers, $\mathrm{HIV1}^{-}$smokers, and $\mathrm{HIV1}^{-}$smokers with low $\mathrm{DL}_{\mathrm{CO}}$.

3.5. Analysis of IL-23 Receptor Expression on Alveolar Macrophages and Lymphocytes. IL-23 is produced by a variety of cell types including AM and its primary target is IL-23 receptor (IL-23R) expressed on lymphocytes. As several reports indicate the presence of IL-23R on alveolar macrophages in diseased lung $[40,41]$, we investigated the presence and expression of this molecule on normal AM. Using GeneSpring Affymetrix analysis with a $p$-call value of $20 \%$ for the threshold for detection of gene expression, we analyzed the AM transcriptome of 87 individuals (24 $\mathrm{HIV1}^{-}$nonsmokers, $34 \mathrm{HIV1}^{-}$smokers, $18 \mathrm{HIV1}^{-}$smokers with low $\mathrm{DL}_{\mathrm{CO}}$, and $11 \mathrm{HIVl}^{+}$smokers with low $\mathrm{DL}_{\mathrm{CO}}$ ). The data demonstrated that the IL-23R was not expressed on AM (not shown). This was consistent with the absence of IL-23R expression in the AM transcriptome of 9 individuals $\mathrm{AM}$ using RNA-Seq (not shown). While IL-23R has been reported to be expressed by AM in sarcoidosis [40], we did not find any evidence of IL-23R expression by AM in normal nonsmokers, $\mathrm{HIV}^{-}$smokers with early emphysema, or $\mathrm{HIV}^{+}$individuals. This conclusion was based on an extensive evaluation of IL23R gene expression (microarray analysis, RNA sequencing, and TaqMan RT-PCR) and flow cytometric analysis of IL-23R expression on the AM. By flow cytometric analysis of freshly isolated cells from BAL, IL-23R was not identified in a gated population of AM, but in a small population of lymphocytes 


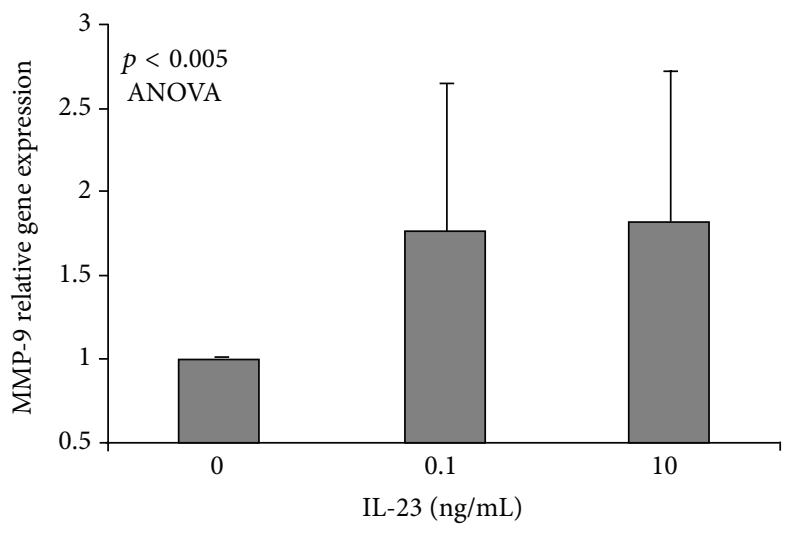

(a)

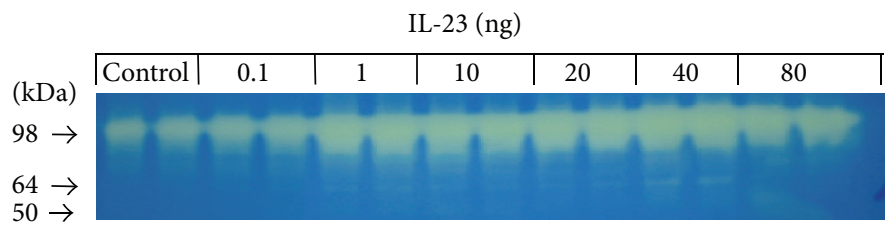

(b)

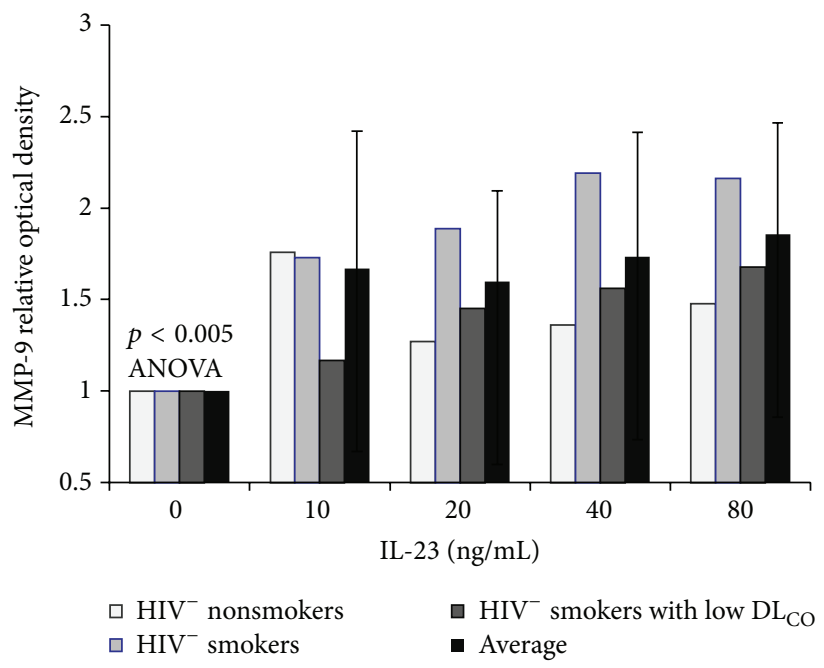

(c)

FIGURE 4: Effect of IL-23 on MMP-9 expression in AM/lymphocyte coculture. (a) Effect of IL-23 (0.1-10 ng/mL) on AM/lymphocyte cocultures $(n=13)$ relative MMP-9 gene expression (mean \pm SEM, $p<0.005$, ANOVA). (b) Gelatin zymography analysis of MMP-9 activity in conditioned media of $\mathrm{HIV1}^{-}$healthy smoker AM/lymphocyte cocultures stimulated with IL-23. Shown is a representative gel. Lanes 1, 2: control; lanes 3, 4: IL-23, $0.1 \mathrm{ng} / \mathrm{mL}$; lanes 5, 6: $1 \mathrm{ng} / \mathrm{mL}$; lanes 7, 8: $10 \mathrm{ng} / \mathrm{mL}$; lanes 9, 10: $20 \mathrm{ng} / \mathrm{mL}$; lanes 11, 12: $40 \mathrm{ng} / \mathrm{mL}$; and lanes 13, 14: $80 \mathrm{ng} / \mathrm{mL}$. (c) Quantitation of gelatin zymography analysis of MMP-9 activity in conditioned media from $10 \mathrm{HIV1}^{-}$nonsmokers $(n=10)$, $\mathrm{HIV1}^{-}$smokers $(n=9)$, and HIV1 ${ }^{-}$smokers with low DLCO $(n=5)$ after stimulation with IL-23 $(0-80 \mathrm{ng} / \mathrm{mL} ; \mathrm{mean} \pm \mathrm{SEM}, p<0.001$ ANOVA).

gated by size, IL-23R staining was positive as shown in a single-specimen representative analysis (Figure 5(a)). The absence of IL-23R on the surface of AM implies that the mechanism of IL-23 induced upregulation of MMP-9 is not a consequence of a direct stimulation of IL-23R on the surface of AM, since IL-23R is present neither on AM of $\mathrm{HIV}^{+}$individuals nor on $\mathrm{AM}$ of smokers with low $\mathrm{DL}_{\mathrm{CO}}$ independent of their HIV1 status.

The response of AM to IL-23 was further evaluated by enrichment of AM in the cultures. Antibodies targeting CD68, a glycoprotein expressed on macrophages but not on lymphocytes, attached to magnetic beads were used to positively select CD68+ AM. After detaching the beads, purified AM were plated on plastic and stimulated with IL-23 in parallel with $\mathrm{AM} / \mathrm{lymphocyte}$ cocultures obtained by the adherence method. AM purified by immunomagnetic bead separation showed no MMP-9 upregulation upon stimulation with IL-23, in contrast to the effect clearly observed in the AM/lymphocytes obtained by adherence (Figure 5(b)). These data indicate that the downstream effects of IL- 23 on MMP9 upregulation are dependent upon nonmacrophage cells residing in the environment.

3.6. The Role of T Cells in IL-23 Induced AM MMP-9 Upregulation. In order to assess the relative proportion of AM in the AM/lymphocyte cocultures obtained by adherence, we analyzed the cultures via flow cytometry and found (1) the proportion of AM was high, similar to or the same as in published literature (>97\%); (2) a small, but clearly identifiable population of lymphocytic cells was present in the cultures (not shown). The largest proportion of the nonadherent cells are $\mathrm{T}$ lymphocytes as confirmed by positive CD2 and CD4/CD8 staining (data not shown). Memory T cells are known to express IL-23R and to be the primary 


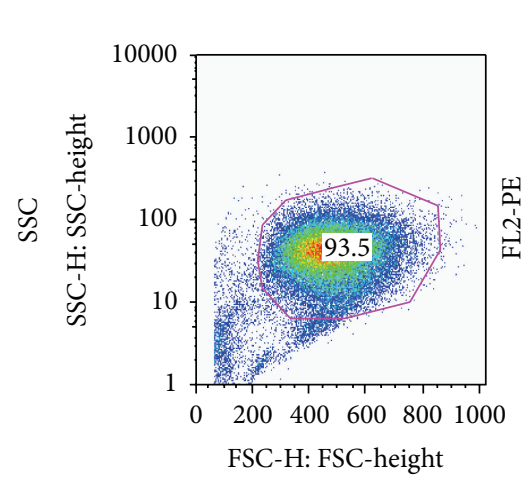

FSC

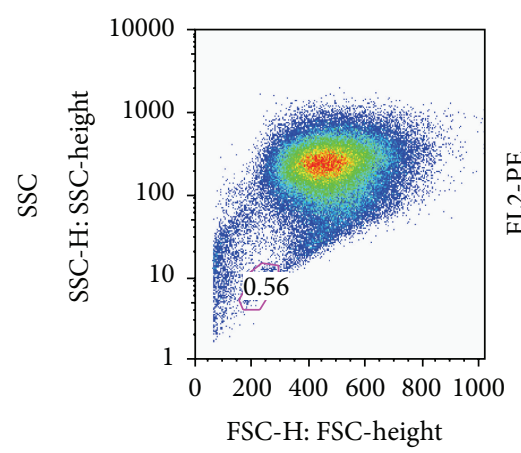

FSC

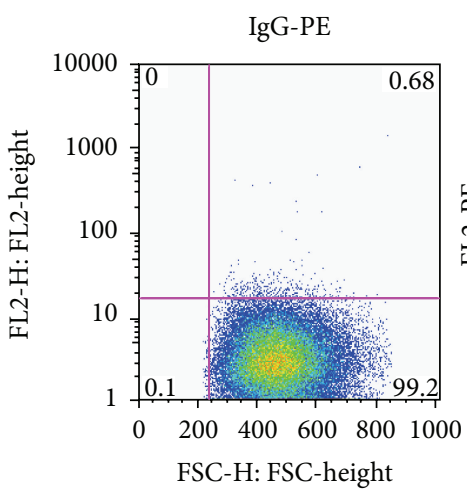

FSC

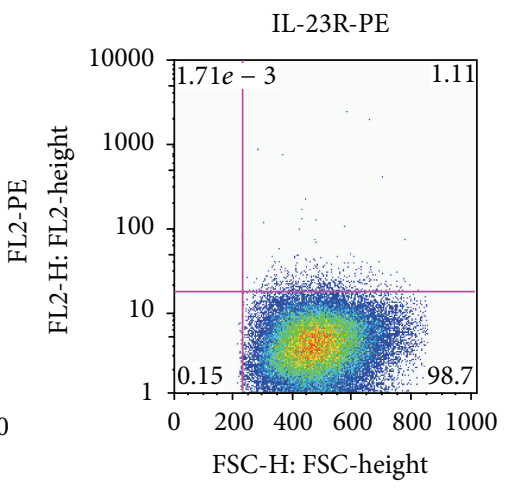

FSC
IgG-PE

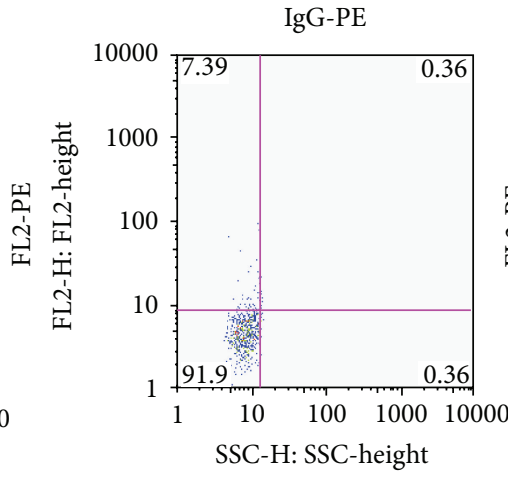

FSC
IL-23R-PE

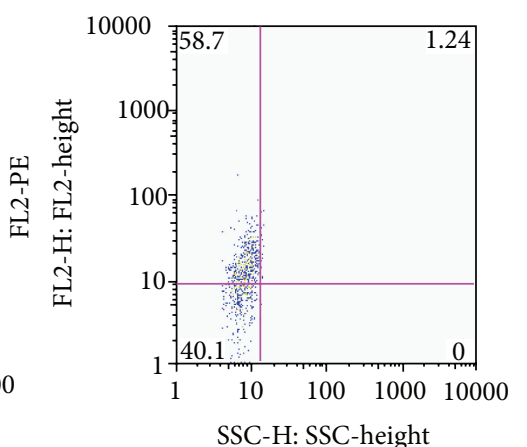

FSC

(a)
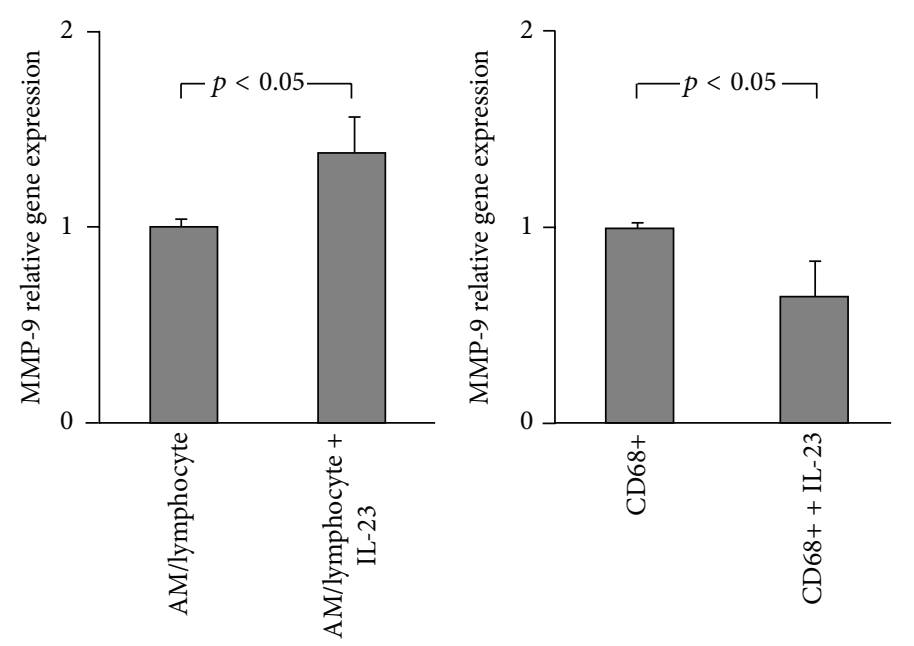

(b)

FIGURE 5: Evaluation of AM and BAL lymphocytes for expression of surface IL-23R. (a) Flow cytometry analysis of cells recovered by lavage from $\mathrm{HIV}^{-}{ }^{-}$smokers with low DLCO. Shown is a representative image from 3 similar experiments. Cells were stained with human IgG-PE (negative control) and mouse anti-human IL-23R-PE antibody $1: 10$. Ordinate: side scatter (SSC). Abscissa: forward scatter (FSC). In the first row, a gated population of AM does not show staining with IL-23R-PE. In the second row, a gated population of lymphocytes shows almost $50 \%$ of cells with positive IL-23R staining. (b) CD68 bead-purified AM do not respond to IL-23. Using detachable CD68-labeled magnetic beads, cells recovered by lavage were treated and AM were positively selected based on their surface expression of CD68. Isolated CD68+ cells were cultured and MMP-9 upregulation upon stimulation with IL-23 was compared to cultures of AM purified by adherence only. In contrast to AM purified via the adherence method, $\mathrm{CD} 68+\mathrm{AM}(n=4)$ do not upregulate MMP-9 upon stimulation with IL-23 (mean \pm SEM). 


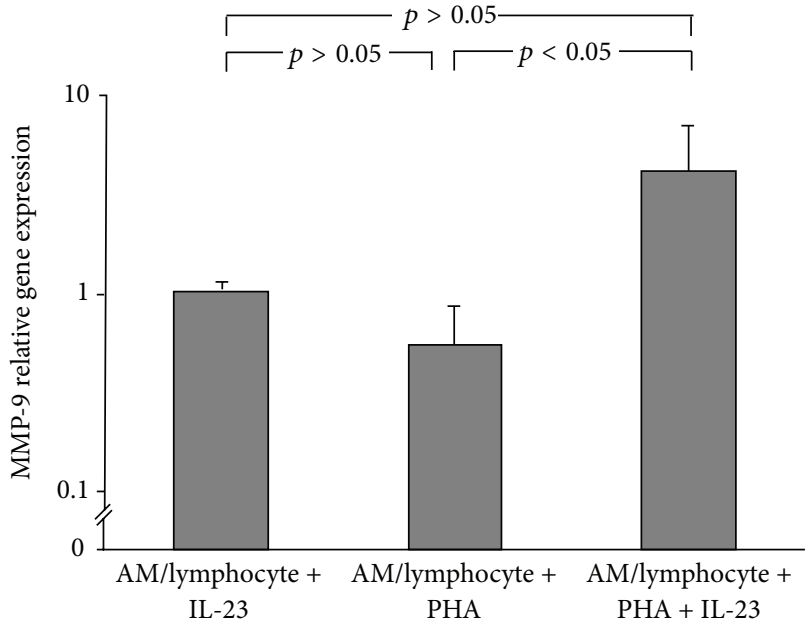

(a)

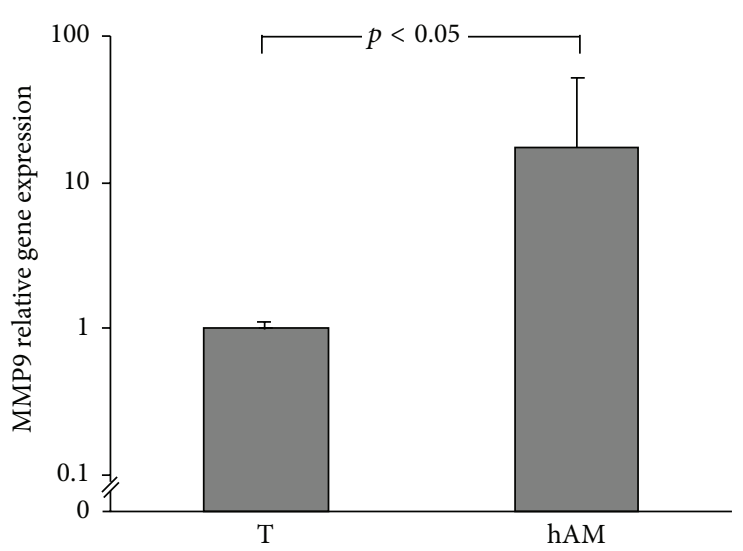

(c)

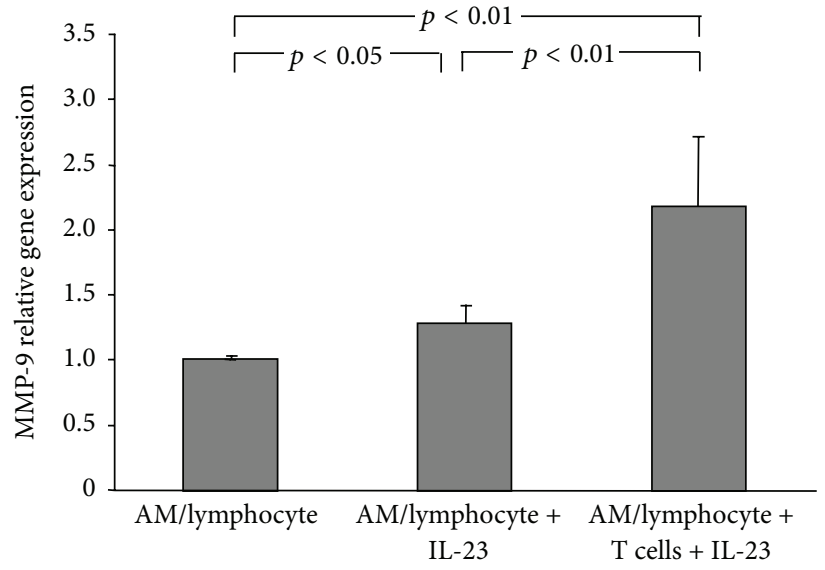

(b)

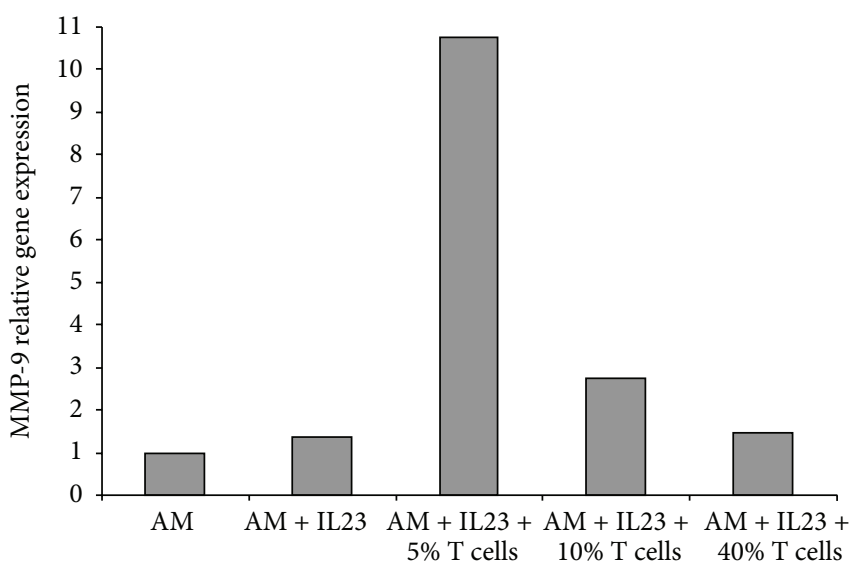

(d)

FIGURE 6: The role of T cells in AM/lymphocyte cocultures in IL-23 induced MMP-9 upregulation. (a) AM/lymphocyte cocultures treated with lymphocyte mitogen PHA $(20 \mu \mathrm{g} / \mathrm{mL})$ respond to IL-23 $(10 \mathrm{ng} / \mathrm{mL})$ in a stronger fashion compared to AM/lymphocyte cocultures stimulated with IL-23 only ( $n=4$, mean \pm SEM, $p<0.05$, Kruskall-Wallis). (b) Purified T cells from lavage (isolated via rosetting with neuraminidase treated sheep RBCs) added to AM/lymphocyte cocultures contribute to stronger upregulation of MMP-9 upon IL-23 cytokine stimulation ( $n=6$, mean \pm SEM, $p<0.01$, ANOVA). (c) AM expression of MMP-9 in comparison to its expression in T cells from BAL. T cells were purified from lavage using CD2 magnetic beads and relative expression of MMP-9 was compared by TaqMan PCR $(n=11$, mean \pm SEM, $p<0.05$, Wilcoxon Signed-Rank Test). (d) The effect of T cells on potentiation of MMP-9 upregulation after IL-23 stimulation (10 ng/mL) of AM/lymphocyte cocultures falls as the number of T cells increases (T cells percentage in AM cultures: $5 \%, 10 \%$, and 40\%; representative results of the effects seen in 4 experiments).

target for the Th17 modulating effect of IL-23 [40, 42-44]. Using IL-23R antibody for labeling the cells from BAL, we observed that IL-23R is expressed in a population of lymphocytes present in $\mathrm{HIV1}^{-}$and $\mathrm{HIV1}^{+}$smokers with early emphysema. We propose that the effect of IL-23 on cocultures of AM/lymphocytes involves T cells as the primary targets for IL-23.

To further assess whether cells other than AM contribute to MMP-9 upregulation, we evaluated the effects of phytohemagglutinin (PHA), a lectin that acts as a specific mitogen for T lymphocytes, on AM/lymphocyte cocultures MMP9 expression. AM/lymphocyte cocultures treated with PHA alone do not upregulate MMP-9. AM/lymphocyte cocultures stimulated with both IL-23 and PHA had increased MMP9 expression in comparison to AM/lymphocyte cocultures stimulated with either PHA or IL-23 alone $(p<0.05$, Kruskall-Wallis, Figure 6(a)).

Based on these data and the fact that $\mathrm{T}$ cell-related chemokine levels were elevated in the ELF of $\mathrm{HIV1}^{+}$smokers with low $\mathrm{DL}_{\mathrm{CO}}$ (Figure 1), we investigated the effect of adding additional $\mathrm{T}$ cells on the release of MMP9 by AM/lymphocyte cocultures stimulated with IL-23. $\mathrm{T}$ cells were isolated from BAL fluid via rosetting with neuraminidase-treated sheep RBCs [32]. AM/lymphocyte cocultures obtained by adherence were treated with IL-23 in the presence or absence of purified $\mathrm{T}$ cells from the BAL and the resulting MMP-9 expression was analyzed via Taqman RT-PCR. Addition of purified T cells from BAL to AM/lymphocyte cocultures leads to a significantly increased expression of MMP-9 $(n=6, p<0.01$, ANOVA, Figure 6(b)). 


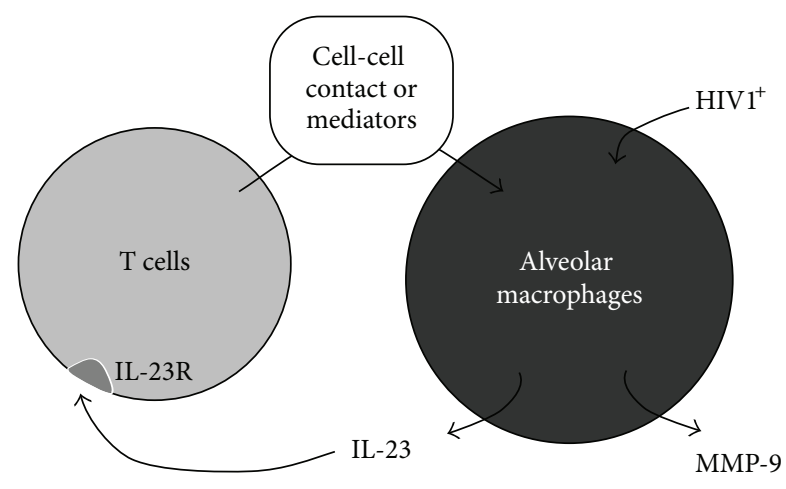

FIgURe 7: Proposed mechanism of IL-23 induced upregulation of AM MMP-9. IL-23 induced production of MMP-9 is indirect and requires the presence of non-AM cells such as T cells ("T") in the alveolar environment. Memory T cells may express IL-23R and are known to be the target of IL-23. Upon stimulation with IL-23, T cells further induce the upregulation of MMP-9 in AM by a mechanism that likely requires direct cell-to-cell contact between $\mathrm{T}$ cells and AM.

Since MMP-9 is produced by blood T cells [45], we compared the gene expression of MMP-9 in two cell types used in this experiment, AM and BAL T cells purified via CD2-labeled magnetic beads. While BAL T cells did produce some MMP-9, there was greater than 1 log higher MMP-9 expression in AM in comparison to alveolar T cells $(p<0.05$, Wilcoxon Signed-Rank Test, Figure 6(c)). In addition, the T cell effect on MMP-9 upregulation is unlikely to be based on T cell MMP-9 expression, because as the percentage of T cells in AM cultures was increased from 5\% to $10 \%$ and to $40 \%$ of total cells MMP-9 expression decreased (Figure 6(d)). Thus, higher percentages of T cells in cultures of AM at the time of harvesting RNA may have simply "diluted" the overall MMP-9 expression in these cultures as T cells express lower levels of MMP-9 mRNA in comparison to AM as discussed above. Alternatively, T cells may exert a biphasic effect on AM MMP-9 expression. While we cannot exclude a possible contributing role from other cell types such as NK cells or neutrophils, these results show that $\mathrm{T}$ cells, while not a major direct contributor to the expression of MMP-9, may represent an important target for IL-23 and may significantly affect overall upregulation of MMP-9 in AM-T-lymphocyte cocultures. Taken together, these observations suggest that, upon stimulation with IL-23, T cells interact with AM leading to the upregulation of AM MMP-9 via a T lymphocyte-AM interaction (Figure 7).

\section{Discussion}

Increased AM and ELF MMP-1 and MMP-9 expression have been linked to emphysema in humans and in animal models [7, 22, 38, 46, 47]. Yearsley et al. [48] were the first to observe increased lung tissue expression of MMP-9 in autopsies of $\mathrm{HIV1}^{+}$individuals with emphysema who died of AIDS. $\mathrm{HIV1}^{+}$smokers with emphysema have both upregulated AM expression of MMPs and upregulated and activated MMPs in ELF compared to $\mathrm{HIV1}^{-}$smokers with emphysema [8].
$\mathrm{HIV1}^{+}$individuals are also known to have increased lung cytokine expression $[5,7,9-12]$. Since several cytokines can upregulate monocyte-derived macrophage MMP expression, it is not unreasonable to hypothesize that these observations may all be directly related [22, 45-47]. Our cytokine array data indicating substantial upregulation of lung cytokines in $\mathrm{HIV}^{+}$individuals are consistent with the broad upregulation of ELF cytokines observed by others [9-12]. Interestingly, in the ELF cytokine profiles, $\mathrm{HIV1}^{-}$smokers with low $\mathrm{DL}_{\mathrm{CO}}$ displayed detectable Th17 related cytokines as a common feature with $\mathrm{HIV}^{+}$nonsmokers and $\mathrm{HIV}^{+}{ }^{+}$smokers with low $\mathrm{DL}_{\mathrm{CO}}$. This increase is not a feature of the cytokine profile of $\mathrm{HIV}^{-}$healthy nonsmokers or $\mathrm{HIV1}^{-}$healthy smokers. The presence of a group of proinflammatory cytokines in the ELF of $\mathrm{HIV}^{+}$nonsmokers which are similar to the cytokine profile in the ELF of $\mathrm{HIV1}^{-}$smokers with low $\mathrm{DL}_{\mathrm{CO}}$ likely plays an important role in the premature development of emphysema in $\mathrm{HIV1}^{+}$individuals who smoke.

The observation of increased Th17 cytokines in the ELF of $\mathrm{HIV1}^{+}$smokers with low $\mathrm{DL}_{\mathrm{CO}}$ is not surprising, as there is emerging evidence of the relevance of Th17 cellular responses in lung pathology [13, 49-51]. The Th17 cellular immune response has been described with recent modification of the Th1/Th2 paradigm based on the identification of IL-23 and IL-17 involvement in autoimmune diseases [44, 52-54]. Th17 cells, characterized by the release of effector-cytokines IL-17, IL-22 and the presence of regulatory-cytokines such as IL23 , are functionally distinct from Th-1 cells and Th-1-related cytokines such as IL-12 and IFN- $\gamma$ [52]. Depending on the timing, the tissue, and the local microenvironment, IL-17secreting cells appear to play both beneficial and detrimental roles in lung immunity and disease [55]. Th17 cells may have a protective role in host defenseagainst certain extracellular bacteria and fungi $[44,51,55,56]$. Th17 cells are localized at the mucosal level, including the gut and lung mucosa, and their cytokine production adds to the first line of defense against infectious agents [57].

Th17 cells and related effector cytokines may also play a prominent role in the pathogenesis of inflammatory lung diseases, where they are hypothesized to promote tissue destruction [50, 51]. Given the significant increase in Th17 related cytokines in stable COPD, it has been inferred that Th17 cellular responses may be driving the chronic inflammation seen in COPD $[13,58]$. Mice exposed to cigarette smoke exhibit enhanced IL-17 production [59], while IL-17 receptor knockout mice are protected from emphysema induced by cigarette smoke exposure [13]. Patients with stable COPD exhibited elevated numbers of IL-22 and IL-23 positively staining cells in the bronchial epithelium and IL-17 positive cells in the submucosa [15]. In ex-smokers with mild to moderate COPD, the number of IL- $17^{+}$cells in the bronchial submucosa is increased compared with nonsmoking control subjects [60]. In the same study, a significant, albeit small, increase in sputum IL-17 has been correlated with airflow obstruction and lung function impairment, but not airway inflammation [60].

Th17 cells are also relevant in HIV1 infection as deterioration of the Th17 lineage may correlate to the rapid progression of the disease in infected individuals [17]. In HIV1 infection, 
Th17 cells are depleted from the gut but remain present in blood and lung [61]. Increased susceptibility of HIV1infected individuals to opportunistic pathogens targeting the respiratory tract such as Pneumocystis carinii and $M$. tuberculosis for which Th17 cells exhibit antigenic specificity suggests that a dysfunction of Th17 cellular responses may correlate with progression of the disease [17, 62, 63].

IL-23 is one of the key cytokines characterizing the Th17 immune response and it represents an important link between the innate and adaptive immune responses [44, 64]. It is a heterodimeric molecule consisting of the p40 subunit shared in common with IL-12, combined with a unique p19 subunit [65]. While both cytokines can induce IFN- $\gamma$ expression in CD4+ cells, IL-23, although not crucial for Th17 differentiation, plays an important role in maintaining Th17 effector function [66]. IL-23 is expressed mostly by activated macrophages and dendritic cells while its receptor, IL-23R (the receptor for the p19 subunit), is expressed in memory $\mathrm{T}$ cells of the Th17 subtype [43]. IL-23 deregulation may lead to inability to adequately protect the organism from certain pathogens while its overexpression may be linked to various autoimmune phenomena [58, 67]. IL-23 gene expression is increased in patients with COPD as compared to nonsmokers and, in an animal model, cigarette smoking increases the lung expression of IL-23 [68]. Increased levels of IL-23 correlate with increased levels of MMPs as detected in mouse models such as TLR4 knock-out mice [69] and in human peripheral blood of patients with relapsing-remitting multiple sclerosis [70]. In support of this concept, intranasal administration of IL-23 protein to mice resulted in increased lung MMP-9, a protease linked to the influx of inflammatory cells into the lung in COPD as well as the destruction of lung tissue in emphysema [21,63]. Based on this background, we hypothesized that, in the lower respiratory tract in $\mathrm{HIV}^{+}$ smokers, increased IL-23 is acting on T-lymphocytes to induce increased AM MMP-9 gene expression and consequently ELF MMP-9 protein levels.

There are multiple pathways by which chronic inflammation may lead to upregulation of MMP-9. Proinflammatory cytokines such as IL-1 $\beta$, TNF- $\alpha$, and IL- 6 are well known to be inducers of MMP-9 expression in monocyte-derived macrophages [47, 70, 71]. Data addressing the effect of IL-23 on production of MMPs are very limited. IL-23 has previously been shown to upregulate MMP-2 in vivo in the ileum of mice infected with Toxoplasma gondii [72]. More specifically for the lung, intranasal application of IL-23 in a mouse model increased MMP-9 levels in ELF and induced IL-17 mRNA expression [21]. Our data support the hypothesis that increased ELF levels of IL-23 may be responsible, at least in part, for the increased ELF MMP-9 in vivo. A limitation of our study is the fact that the observed increase in MMP9 in the lungs of $\mathrm{HIVl}^{+}$smokers with low $\mathrm{DL}_{\mathrm{CO}}$ may be a consequence of increased IL-23 in the ELF, but causality has been proven only in vitro.

Memory T cells are known to express IL-23R and to be the primary target for the Th17 modulating effect of IL-23 [ 40 , $42,44]$. We propose that the effect of IL- 23 on cocultures of $\mathrm{AM} / \mathrm{lym}$ phocytes involves $\mathrm{T}$ cells as the primary targets for IL-23.
Our observations suggest that, upon stimulation with IL23, T cells interact with AM leading to the upregulation of AM MMP-9. There are several possible mechanisms that might explain this relationship between AM and T cells. Given its identification in ELF in the same phenotypes in which IL-23 is present, IFN- $\gamma$ was evaluated as a potential target cytokine. While IFN- $\gamma$ is indeed upregulated in T cells upon IL-23 stimulation consistent with previously reported data [73] and confirmed by our in vitro experiments, IFN- $\gamma$ does not induce upregulation of MMP-9 in human AM (not shown). In addition, we were unable to passively transfer the effect on AM MMP-9 upregulation by adding conditioned media from $\mathrm{T}$ cell cultures stimulated with IL-23. This observation suggests that that direct cell/cell contact may be required. The relevance of the T-lymphocyte/monocyte interaction for the induction of MMP-9 expression has been described $[6,74$, 75]. Various stimuli induce T-lymphocytes to activate monocytes indirectly via released cytokines and directly via direct cellular contact that may include antigen recognition on antigen specific $\mathrm{T}$ cell clones, cross-linking of surface receptors, or membrane-associated cytokines [76]. In addition to membrane-associated cytokines, other surface molecules have been assessed for their ability to activate monocytes upon contact with stimulated T-cells, for example, leukocyte function antigen- (LFA-) 1/intercellular adhesion molecule1, CD2/LFA3, CD40/CD40L, and lymphocyte activationantigen-3 [76]. CD40 is a costimulatory protein found on antigen presenting cells and is required for their activation. The binding of CD154 (CD40L) on Th cells to CD40 activates antigen presenting cells and induces a variety of downstream effects. CD40-ligand (CD-40L) is a member of the tumor necrosis factor (TNF) superfamily and activated CD4+ T cells are the predominant CD40L expressing population [77]. IL-23 administration to peripheral blood T cells in vitro upregulated CD40L expression (not shown). One possibility is that this upregulation of CD40L may lead to enhancement of the direct T cell-AM activation which may further induce the upregulation of MMP-9 in AM.

\section{Conclusions}

Our data support the hypothesis that IL-23 upregulates MMP-9 in the lung. This effect is indirect and requires both AM and T lymphocytes. Taken together, these data suggest that the Th17 pathway may play a role in the early development of emphysema in $\mathrm{HIV1}^{+}$individuals.

\section{Disclosure}

Current address is Division of Pulmonary and Critical Care, David Geffen School of Medicine, UCLA, Los Angeles, CA.

\section{Competing Interests}

The authors declare that they have no competing interests.

\section{Authors' Contributions}

Igor Z. Barjaktarevic contributed to conception and design, collection/assembly of data, data analysis and interpretation, 
paper writing, and final approval of paper; Ronald G. Crystal contributed to conception and design, provision of study material or patients, data analysis and interpretation, paper writing, final approval of paper, and financial support; Robert J. Kaner contributed to conception and design, provision of study material or patients, collection/assembly of data, data analysis and interpretation, paper writing, final approval of paper, and financial support.

\section{Acknowledgments}

The authors thank JunMei Hu, Maryna Elnashar, and Anja Krause for help with flow cytometry, Jacqueline Salit for Affymetrix Microarray data analysis, Juan-Rodriguez Flores for RNA sequencing, Francisco Santiago for JRFL infection in vitro of alveolar macrophages, Domenick Falcone for helpful discussions, and N. Mohamed for help in preparing this paper. This study was supported in part by R01HL118857, R34HL11735, UL1TR000457, and P50HL084936. Robert J. Kaner is supported, in part, by The JP Smith Clinical Scholar award.

\section{References}

[1] N. F. Crum, R. H. Riffenburgh, S. Wegner et al., "Comparisons of causes of death and mortality rates among HIV-infected persons: analysis of the pre-, early, and late HAART (highly active antiretroviral therapy) eras," Journal of Acquired Immune Deficiency Syndromes, vol. 41, no. 2, pp. 194-200, 2006.

[2] K. Crothers, A. A. Butt, C. L. Gibert, M. C. Rodriguez-Barradas, S. Crystal, and A. C. Justice, "Increased COPD among HIVpositive compared to HIV-negative veterans," Chest, vol. 130, no. 5, pp. 1326-1333, 2006.

[3] K. Crothers, "Chronic obstructive pulmonary disease in patients who have HIV infection," Clinics in Chest Medicine, vol. 28, no. 3, pp. 575-587, 2007.

[4] P. T. Diaz, M. A. King, E. R. Pacht et al., "Increased susceptibility to pulmonary emphysema among HIV-seropositive smokers," Annals of Internal Medicine, vol. 132, no. 5, pp. 369-372, 2000.

[5] I. Petrache, K. Diab, K. S. Knox et al., "HIV associated pulmonary emphysema: a review of the literature and inquiry into its mechanism," Thorax, vol. 63, no. 5, pp. 463-469, 2008.

[6] E. J. Goetzl, M. J. Banda, and D. Leppert, "Matrix metalloproteinases in immunity," Journal of Immunology, vol. 156, no. 1, pp. 1-4, 1996.

[7] W. MacNee, "Pathogenesis of chronic obstructive pulmonary disease," Clinics in Chest Medicine, vol. 28, no. 3, pp. 479-513, 2007.

[8] R. J. Kaner, F. Santiago, and R. G. Crystal, "Up-regulation of alveolar macrophage matrix metalloproteinases in $\mathrm{HIV1}^{+}$ smokers with early emphysema," Journal of Leukocyte Biology, vol. 86, no. 4, pp. 913-922, 2009.

[9] E. V. Nguyen, S. A. Gharib, K. Crothers et al., "Proteomic landscape of bronchoalveolar lavage fluid in human immunodeficiency virus infection," American Journal of Physiology - Lung Cellular and Molecular Physiology, vol. 306, no. 1, pp. L35-L42, 2014.

[10] H. L. Twigg III, G. K. Iwamoto, and D. M. Soliman, "Role of cytokines in alveolar macrophage accessory cell function in
HIV-infected individuals," Journal of Immunology, vol. 149, no. 4, pp. 1462-1469, 1992.

[11] C. Agostini, R. Sancetta, A. Cerutti, and G. Semenzato, "Alveolar macrophages as a cell source of cytokine hyperproduction in HIV-related interstitial lung disease," Journal of Leukocyte Biology, vol. 58, no. 5, pp. 495-500, 1995.

[12] R. Buhl, H. A. Jaffe, K. J. Holroyd et al., "Activation of alveolar macrophages in asymptomatic HIV-infected individuals," Journal of Immunology, vol. 150, no. 3, pp. 1019-1028, 1993.

[13] J. F. Alcorn, C. R. Crowe, and J. K. Kolls, "TH17 cells in asthma and COPD," Annual Review of Physiology, vol. 72, pp. 495-516, 2009.

[14] M. Shan, H.-F. Cheng, L.-Z. Song et al., "Lung myeloid dendritic cells coordinately induce TH1 and TH17 responses in human emphysema," Science Translational Medicine, vol. 1, no. 4, article 4ra10, 2009.

[15] A. Di Stefano, G. Caramori, I. Gnemmi et al., "T helper type 17related cytokine expression is increased in the bronchial mucosa of stable chronic obstructive pulmonary disease patients," Clinical and Experimental Immunology, vol. 157, no. 2, pp. 316324, 2009.

[16] M. Alfano, A. Crotti, E. Vicenzi, and G. Poli, "New players in cytokine control of HIV infection," Current HIV/AIDS Reports, vol. 5, no. 1, pp. 27-32, 2008.

[17] P. Ancuta, P. Monteiro, and R.-P. Sekaly, "Th17 lineage commitment and HIV-1 pathogenesis," Current Opinion in HIV and AIDS, vol. 5, no. 2, pp. 158-165, 2010.

[18] W. Maek-A-Nantawat, S. Buranapraditkun, J. Klaewsongkram, and $\mathrm{K}$. Ruxrungthum, "Increased interleukin-17 production both in helper T cell subset Th17 and CD4-negative T cells in human immunodeficiency virus infection," Viral Immunology, vol. 20, no. 1, pp. 66-75, 2007.

[19] A. Singh, M. Vajpayee, S. A. Ali, and N. K. Chauhan, "Cellular interplay among Th17, Th1, and Treg cells in HIV-1 subtype 'C' infection," Journal of Medical Virology, vol. 86, no. 3, pp. 372384, 2014.

[20] G. R. Yannam, T. Gutti, and L. Y. Poluektova, "IL-23 in infections, inflammation, autoimmunity and cancer: possible role in HIV-1 and AIDS," Journal of Neuroimmune Pharmacology, vol. 7, no. 1, pp. 95-112, 2012.

[21] S. Ivanov, S. Bozinovski, A. Bossios et al., "Functional relevance of the IL-23-IL-17 axis in lungs in vivo," American Journal of Respiratory Cell and Molecular Biology, vol. 36, pp. 442-451, 2007.

[22] J. J. Atkinson and R. M. Senior, "Matrix metalloproteinase-9 in lung remodeling," American Journal of Respiratory Cell and Molecular Biology, vol. 28, no. 1, pp. 12-24, 2003.

[23] N. MacIntyre, R. O. Crapo, G. Viegi et al., "Standardisation of the single-breath determination of carbon monoxide uptake in the lung," European Respiratory Journal, vol. 26, no. 4, pp. 720 735, 2005.

[24] M. R. Miller, R. Crapo, J. Hankinson et al., "General considerations for lung function testing," European Respiratory Journal, vol. 26, no. 1, pp. 153-161, 2005.

[25] M. R. Miller, J. Hankinson, V. Brusasco et al., "Standardisation of spirometry," European Respiratory Journal, vol. 26, no. 2, pp. 319-338, 2005

[26] J. Wanger, J. L. Clausen, A. Coates et al., "Standardisation of the measurement of lung volumes," European Respiratory Journal, vol. 26, no. 3, pp. 511-522, 2005. 
[27] C. Gordon, K. Gudi, A. Krause et al., "Circulating endothelial microparticles as a measure of early lung destruction in cigarette smokers," American Journal of Respiratory and Critical Care Medicine, vol. 184, no. 2, pp. 224-232, 2011.

[28] J. M. Hughes and D. V. Bates, "Historical review: the carbon monoxide diffusing capacity (DLCO) and its membrane (DM) and red cell (Theta.Vc) components," Respiratory Physiology \& Neurobiology, vol. 138, pp. 115-142, 2003.

[29] M. Engele, E. Stößel, K. Castiglione et al., "Induction of TNF in human alveolar macrophages as a potential evasion mechanism of virulent Mycobacterium tuberculosis," The Journal of Immunology, vol. 168, no. 3, pp. 1328-1337, 2002.

[30] R. J. Kaner, F. Santiago, F. Rahaghi, E. Michaels, J. P. Moore, and R. G. Crystal, "Adenovirus vectors block human immunodeficiency virus-1 replication in human alveolar macrophages by inhibition of the long terminal repeat," American Journal of Respiratory Cell and Molecular Biology, vol. 43, no. 2, pp. 234242, 2010.

[31] B. W. S. Robinson, T. L. McLemore, and R. G. Crystal, "Gamma interferon is spontaneously released by alveolar macrophages and lung $\mathrm{T}$ lymphocytes in patients with pulmonary sarcoidosis," Journal of Clinical Investigation, vol. 75, no. 5, pp. 1488-1495, 1985.

[32] A. Venet, A. J. Hance, C. Saltini, B. W. Robinson, and R. G. Crystal, "Enhanced alveolar macrophage-mediated antigeninduced T-lymphocyte proliferation in sarcoidosis," The Journal of Clinical Investigation, vol. 75, no. 1, pp. 293-301, 1985.

[33] J. St-Laurent, V. Turmel, L.-P. Boulet, and E. Bissonnette, "Alveolar macrophage subpopulations in bronchoalveolar lavage and induced sputum of asthmatic and control subjects," Journal of Asthma, vol. 46, no. 1, pp. 1-8, 2009.

[34] S. J. Hodge, G. L. Hodge, M. Holmes, and P. N. Reynolds, "Flow cytometric characterization of cell populations in bronchoalveolar lavage and bronchial brushings from patients with chronic obstructive pulmonary disease," Cytometry Part BClinical Cytometry, vol. 61, no. 1, pp. 27-34, 2004.

[35] B. J. Carolan, B.-G. Harvey, B. P. De, H. Vanni, and R. G. Crystal, "Decreased expression of intelectin 1 in the human airway epithelium of smokers compared to nonsmokers," The Journal of Immunology, vol. 181, no. 8, pp. 5760-5767, 2008.

[36] R. Montes-Vizuet, A. Vega-Miranda, E. Valencia-Maqueda, M. C. Negrete-García, J. R. Velásquez, and L. M. Teran, "CC chemokine ligand 1 is released into the airways of atopic asthmatics," European Respiratory Journal, vol. 28, no. 1, pp. 5967, 2006.

[37] N. Ogawa, T. Kawanami, K. Shimoyama, L. Ping, and S. Sugai, "Expression of interferon-inducible T cell $\alpha$ chemoattractant (CXCL11) in the salivary glands of patients with Sjögren's syndrome," Clinical Immunology, vol. 112, no. 3, pp. 235-238, 2004.

[38] S. Chakrabarti and K. D. Patel, "Matrix metalloproteinase-2 (MMP-2) and MMP-9 in pulmonary pathology," Experimental Lung Research, vol. 31, no. 6, pp. 599-621, 2005.

[39] P. Van Lint and C. Libert, "Chemokine and cytokine processing by matrix metalloproteinases and its effect on leukocyte migration and inflammation," Journal of Leukocyte Biology, vol. 82, no. 6, pp. 1375-1381, 2007.

[40] M. Facco, A. Cabrelle, A. Teramo et al., "Sarcoidosis is a Th1/Th17 multisystem disorder," Thorax, vol. 66, no. 2, pp. 144150, 2011.

[41] J. Li, L. Zhang, J. Zhang et al., "Interleukin 23 regulates proliferation of lung cancer cells in a concentration-dependent way in association with the interleukin-23 receptor," Carcinogenesis, vol. 34, no. 3, pp. 658-666, 2013.

[42] F. Annunziato, L. Cosmi, F. Liotta, E. Maggi, and S. Romagnani, "The phenotype of human Th17 cells and their precursors, the cytokines that mediate their differentiation and the role of Th17 cells in inflammation," International Immunology, vol. 20, no. 11, pp. 1361-1368, 2008.

[43] R. A. Kastelein, C. A. Hunter, and D. J. Cua, "Discovery and biology of IL-23 and IL-27: related but functionally distinct regulators of inflammation," Annual Review of Immunology, vol. 25, pp. 221-242, 2007.

[44] T. Korn, E. Bettelli, M. Oukka, and V. K. Kuchroo, "IL-17 and Th17 cells," Annual Review of Immunology, vol. 27, pp. 485-517, 2009.

[45] E. Oviedo-Orta, A. Bermudez-Fajardo, S. Karanam, U. Benbow, and A. C. Newby, "Comparison of MMP-2 and MMP-9 secretion from Thelper 0, 1 and 2 lymphocytes alone and in coculture with macrophages,' Immunology, vol. 124, no. 1, pp. 42-50, 2008.

[46] G. A. Finlay, L. R. O’Driscoll, K. J. Russell et al., "Matrix metalloproteinase expression and production by alveolar macrophages in emphysema," American Journal of Respiratory and Critical Care Medicine, vol. 156, no. 1, pp. 240-247, 1997.

[47] K. J. Greenlee, Z. Werb, and F. Kheradmand, "Matrix metalloproteinases in lung: multiple, multifarious, and multifaceted," Physiological Reviews, vol. 87, no. 1, pp. 69-98, 2007.

[48] M. M. Yearsley, P. T. Diaz, D. Knoell, and G. J. Nuovo, "Correlation of HIV-1 detection and histology in AIDS-associated emphysema," Diagnostic Molecular Pathology, vol. 14, no. 1, pp. 48-52, 2005.

[49] E. Torrado and A. M. Cooper, "IL-17 and Th17 cells in tuberculosis," Cytokine and Growth Factor Reviews, vol. 21, no. 6, pp. 455-462, 2010.

[50] S. L. Traves and L. E. Donnelly, "Th17 cells in airway diseases," Current Molecular Medicine, vol. 8, no. 5, pp. 416-426, 2008.

[51] H.-C. Tsai, S. Velichko, L.-Y. Hung, and R. Wu, "IL-17A and Th17 cells in lung inflammation: an update on the role of Th17 cell differentiation and IL-17R signaling in host defense against infection," Clinical and Developmental Immunology, vol. 2013, Article ID 267971, 12 pages, 2013.

[52] L. E. Harrington, P. R. Mangan, and C. T. Weaver, "Expanding the effector CD4 T-cell repertoire: the Th17 lineage," Current Opinion in Immunology, vol. 18, no. 3, pp. 349-356, 2006.

[53] J. K. Kolls and A. Lindén, "Interleukin-17 family members and inflammation," Immunity, vol. 21, no. 4, pp. 467-476, 2004.

[54] B. Stockinger, M. Veldhoen, and B. Martin, “Th17 T cells: linking innate and adaptive immunity," Seminars in Immunology, vol. 19, no. 6, pp. 353-361, 2007.

[55] M. J. McGeachy and S. J. McSorley, "Microbial-induced Th17: superhero or supervillain?” The Journal of Immunology, vol. 189, no. 7, pp. 3285-3291, 2012.

[56] M. S. Maddur, P. Miossec, S. V. Kaveri, and J. Bayry, “Th17 cells: biology, pathogenesis of autoimmune and inflammatory diseases, and therapeutic strategies," The American Journal of Pathology, vol. 181, no. 1, pp. 8-18, 2012.

[57] D. Mucida and S. Salek-Ardakani, "Regulation of TH17 cells in the mucosal surfaces," Journal of Allergy and Clinical Immunology, vol. 123, no. 5, pp. 997-1003, 2009.

[58] R. A. Holloway and L. E. Donnelly, "Immunopathogenesis of chronic obstructive pulmonary disease," Current Opinion in Pulmonary Medicine, vol. 19, no. 2, pp. 95-102, 2013. 
[59] B. N. Melgert, W. Timens, H. A. Kerstjens et al., "Effects of 4 months of smoking in mice with ovalbumin-induced airway inflammation," Clinical and Experimental Allergy, vol. 37, no. 12, pp. 1798-1808, 2007.

[60] C. Doe, M. Bafadhel, S. Siddiqui et al., "Expression of the T helper 17-associated cytokines IL-17A and IL-17F in asthma and COPD," Chest, vol. 138, no. 5, pp. 1140-1147, 2010.

[61] J. M. Brenchley, M. Paiardini, K. S. Knox et al., "Differential Th17 CD4 T-cell depletion in pathogenic and nonpathogenic lentiviral infections," Blood, vol. 112, no. 7, pp. 2826-2835, 2008.

[62] P. J. Dubin and J. K. Kolls, "Th17 cytokines and mucosal immunity," Immunological Reviews, vol. 226, no. 1, pp. 160-171, 2008.

[63] J. K. Kolls and S. A. Khader, "The role of Th17 cytokines in primary mucosal immunity," Cytokine and Growth Factor Reviews, vol. 21, no. 6, pp. 443-448, 2010.

[64] C. L. Langrish, B. S. McKenzie, N. J. Wilson, R. De Waal Malefyt, R. A. Kastelein, and D. J. Cua, "IL-12 and IL-23: master regulators of innate and adaptive immunity," Immunological Reviews, vol. 202, pp. 96-105, 2004.

[65] B. Oppmann, R. Lesley, B. Blom et al., "Novel p19 protein engages IL-12p40 to form a cytokine, IL-23, with biological activities similar as well as distinct from IL-12," Immunity, vol. 13, no. 5, pp. 715-725, 2000.

[66] T. Zelante, A. De Luca, P. Bonifazi et al., "IL-23 and the Th17 pathway promote inflammation and impair antifungal immune resistance," European Journal of Immunology, vol. 37, no. 10, pp. 2695-2706, 2007.

[67] L. Romani, T. Zelante, A. De Luca, F. Fallarino, and P. Puccetti, "IL-17 and therapeutic kynurenines in pathogenic inflammation to fungi," Journal of Immunology, vol. 180, no. 8, pp. 5157-5162, 2008.

[68] Y. Iwakura and H. Ishigame, "The IL-23/IL-17 axis in inflammation," The Journal of Clinical Investigation, vol. 116, no. 5, pp. 1218-1222, 2006.

[69] M. Naseemuddin, A. Iqbal, T. H. Nasti, J. L. Ghandhi, A. D. Kapadia, and N. Yusuf, "Cell mediated immune responses through TLR4 prevents DMBA-induced mammary carcinogenesis in mice," International Journal of Cancer, vol. 130, no. 4, pp. 765-774, 2012.

[70] J. S. Alexander, M. K. Harris, S. R. Wells et al., "Alterations in serum MMP-8, MMP-9, IL-12p40 and IL-23 in multiple sclerosis patients treated with interferon- $\beta \mathrm{lb}$, , Multiple Sclerosis, vol. 16, no. 7, pp. 801-809, 2010.

[71] G. M. Gordon, D. R. Ledee, W. J. Feuer, and M. E. Fini, "Cytokines and signaling pathways regulating matrix metalloproteinase-9 (MMP-9) expression in corneal epithelial cellsy," Journal of Cellular Physiology, vol. 221, no. 2, pp. 402-411, 2009.

[72] M. Muñoz, M. M. Heimesaat, K. Danker et al., "Interleukin (IL)23 mediates Toxoplasma gondii-induced immunopathology in the gut via matrixmetalloproteinase-2 and IL-22 but independent of IL-17," Journal of Experimental Medicine, vol. 206, no. 13, pp. 3047-3059, 2009.

[73] S. Buonocore, P. P. Ahern, H. H. Uhlig et al., "Innate lymphoid cells drive interleukin-23-dependent innate intestinal pathology," Nature, vol. 464, no. 7293, pp. 1371-1375, 2010.

[74] S. Ferrari-Lacraz, L. P. Nicod, R. Chicheportiche, H. G. Welgus, and J.-M. Dayer, "Human lung tissue macrophages, but not alveolar macrophages, express matrix metalloproteinases after direct contact with activated T lymphocytes," American Journal of Respiratory Cell and Molecular Biology, vol. 24, no. 4, pp. 442451, 2001.

[75] S. Lacraz, P. Isler, E. Vey, H. G. Welgus, and J.-M. Dayer, "Direct contact between T lymphocytes and monocytes is a major pathway for induction of metalloproteinase expression," The Journal of Biological Chemistry, vol. 269, no. 35, pp. 2202722033, 1994.

[76] J.-M. Dayer, "How T-lymphocytes are activated and become activators by cell-cell interaction," European Respiratory Journal, Supplement, vol. 22, no. 44, 2003.

[77] I. S. Grewal and R. A. Flavel, "The role of CD40 ligand in costimulation and T-cell activation," Immunological Reviews, vol. 153, pp. 85-106, 1996. 


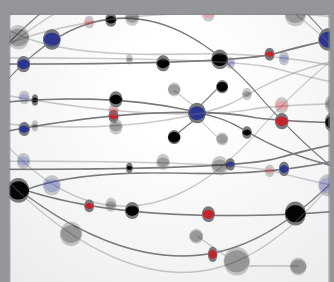

The Scientific World Journal
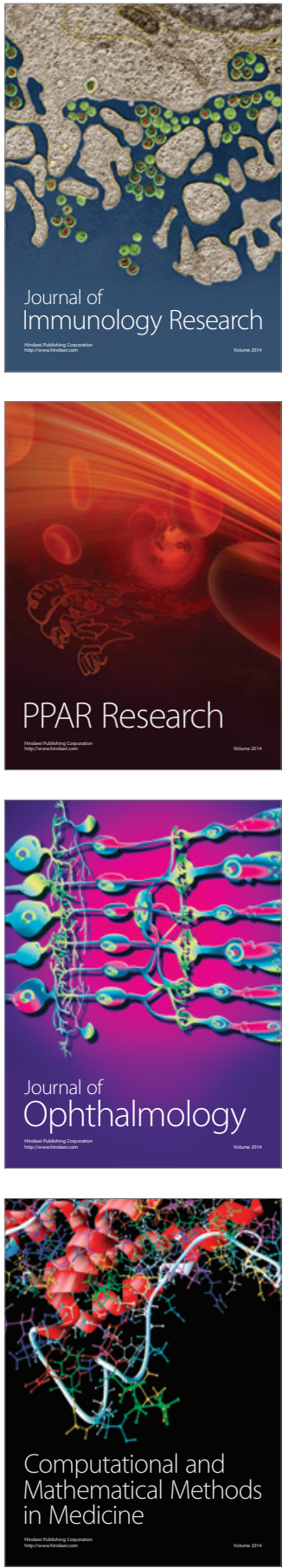

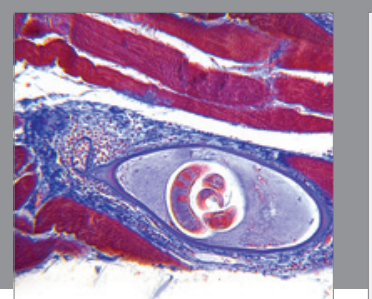

Gastroenterology Research and Practice

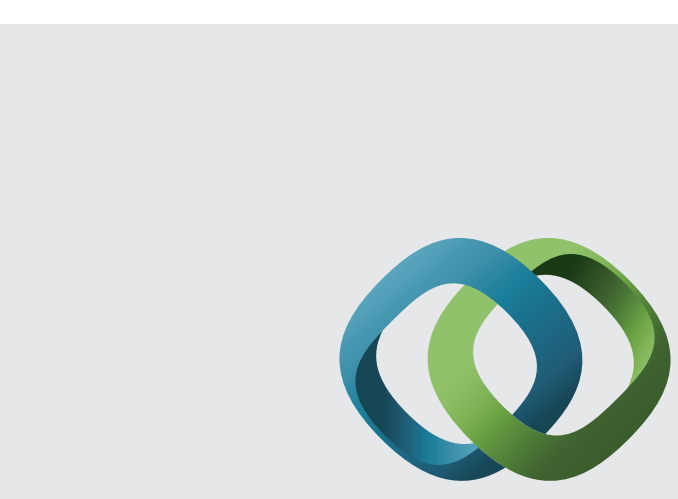

\section{Hindawi}

Submit your manuscripts at

http://www.hindawi.com
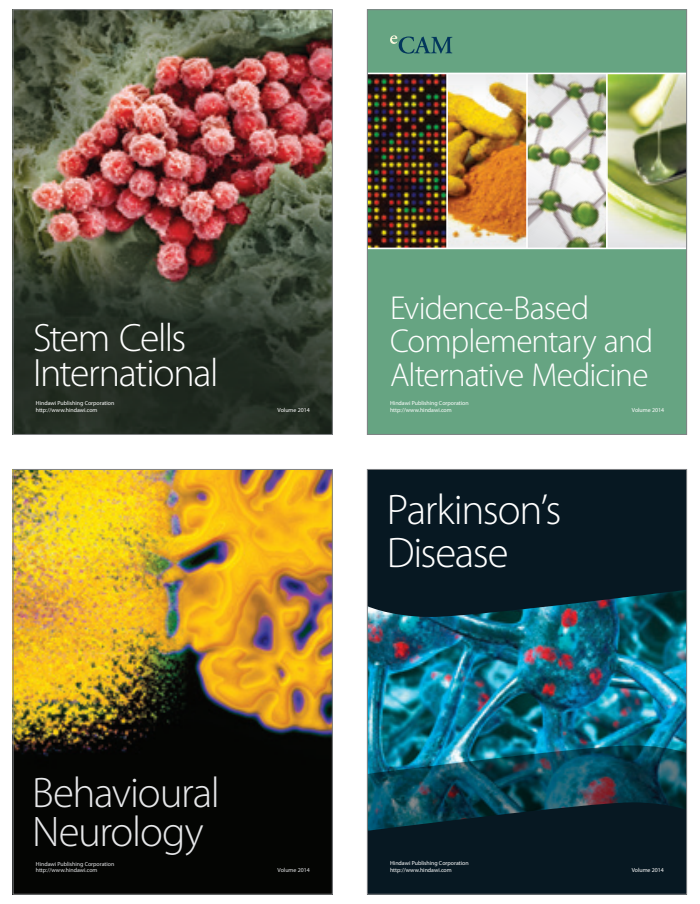
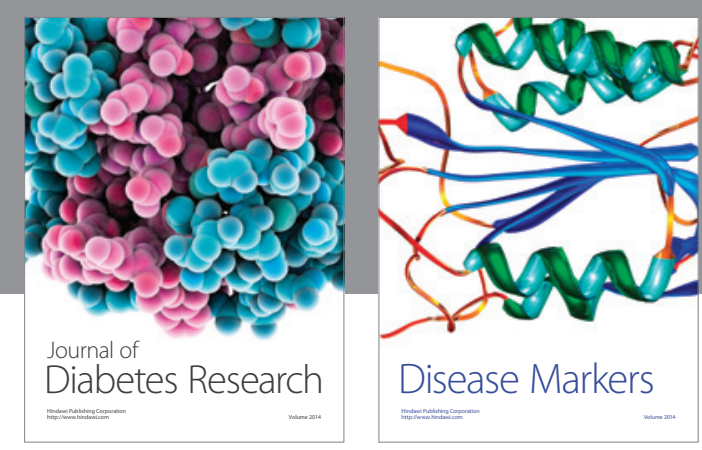

Disease Markers
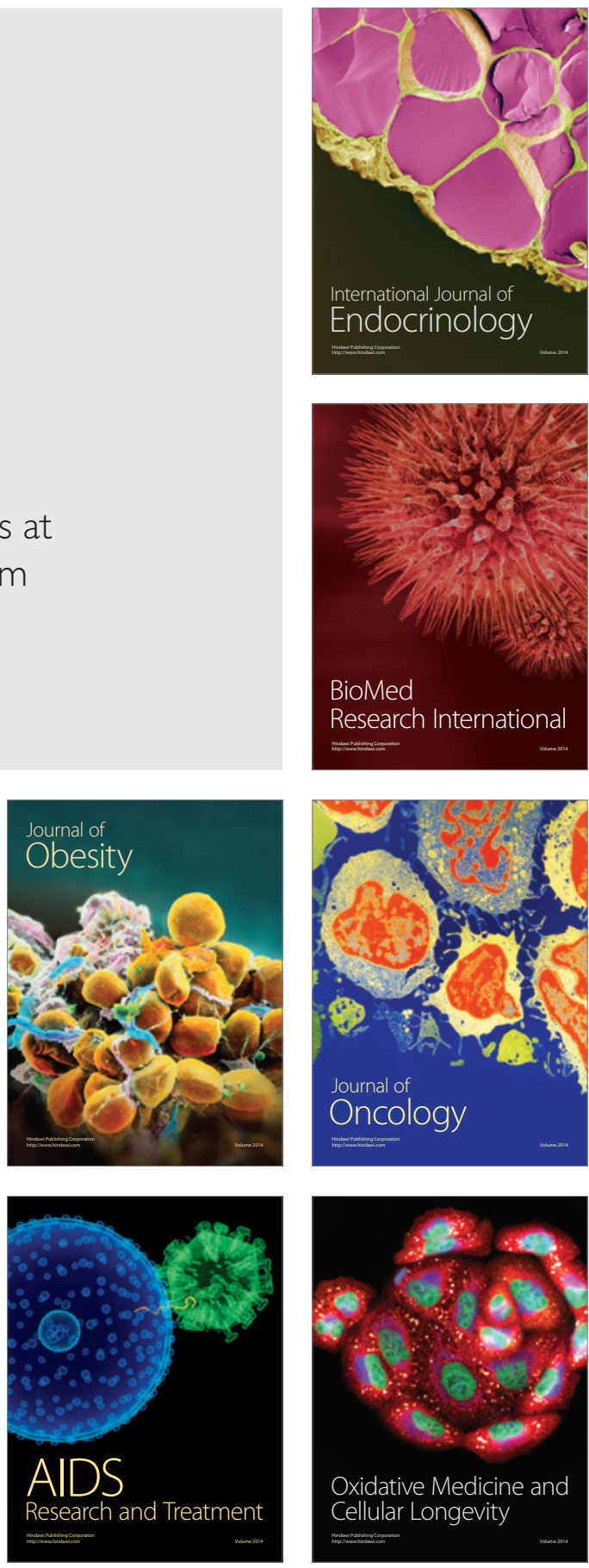